\title{
High-Pressure Mechanical Response of Two Vitreous Silicates
}
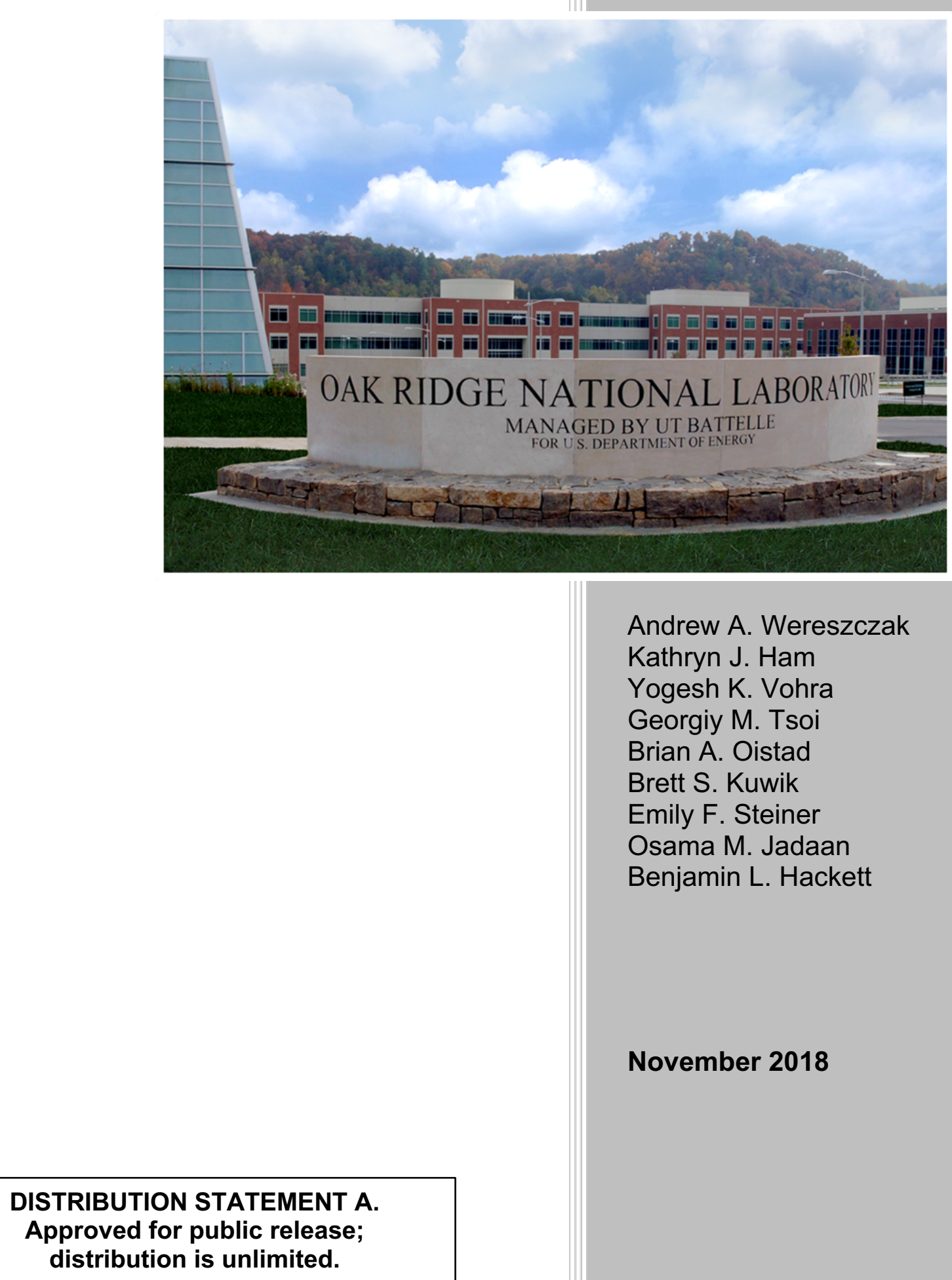

Andrew A. Wereszczak

Kathryn J. Ham

Yogesh K. Vohra

Georgiy M. Tsoi

Brian A. Oistad

Brett S. Kuwik

Emily F. Steiner

Osama M. Jadaan

Benjamin L. Hackett

November 2018 


\title{
DOCUMENT AVAILABILITY
}

Reports produced after January 1, 1996, are generally available free via US Department of Energy (DOE) SciTech Connect.

Website www.osti.gov

Reports produced before January 1, 1996, may be purchased by members of the public from the following source:

\author{
National Technical Information Service \\ 5285 Port Royal Road \\ Springfield, VA 22161 \\ Telephone 703-605-6000 (1-800-553-6847) \\ TDD 703-487-4639 \\ Fax 703-605-6900 \\ E-mail info@ntis.gov \\ Website http://classic.ntis.gov/
}

Reports are available to DOE employees, DOE contractors, Energy Technology Data Exchange representatives, and International Nuclear Information System representatives from the following source:

Office of Scientific and Technical Information

PO Box 62

Oak Ridge, TN 37831

Telephone 865-576-8401

Fax 865-576-5728

E-mail reports@osti.gov

Website http://www.osti.gov/contact.html

This report was prepared as an account of work sponsored by an agency of the United States Government. Neither the United States Government nor any agency thereof, nor any of their employees, makes any warranty, express or implied, or assumes any legal liability or responsibility for the accuracy, completeness, or usefulness of any information, apparatus, product, or process disclosed, or represents that its use would not infringe privately owned rights. Reference herein to any specific commercial product, process, or service by trade name, trademark, manufacturer, or otherwise, does not necessarily constitute or imply its endorsement, recommendation, or favoring by the United States Government or any agency thereof. The views and opinions of authors expressed herein do not necessarily state or reflect those of the United States Government or any agency thereof. 
Materials Science and Technology Division

\title{
High-Pressure Mechanical Response of Two Vitreous Silicates
}

\author{
Andrew A. Wereszczak \\ Kathryn J. Ham \\ Yogesh K. Vohra \\ Georgiy M. Tsoi \\ Brian A. Oistad \\ Brett S. Kuwik \\ Emily F. Steiner \\ Osama M. Jadaan \\ Benjamin L. Hackett
}

November 2018

Prepared by OAK RIDGE NATIONAL LABORATORY

Oak Ridge, TN 37831-6283

managed by

UT-BATTELLE, LLC

for the

US DEPARTMENT OF ENERGY

under contract DE-AC05-00OR22725 



\section{CONTENTS}

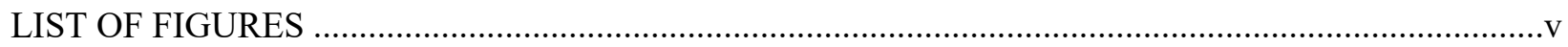

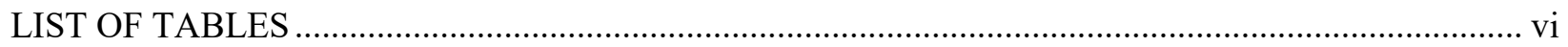

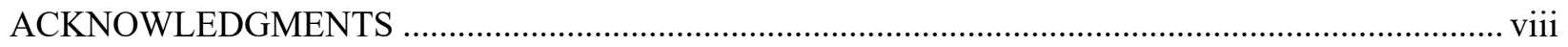

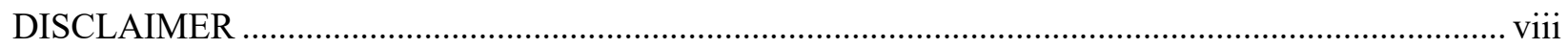

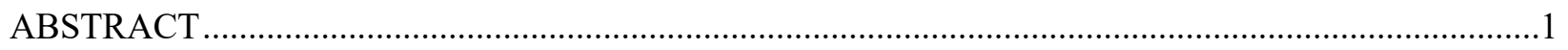

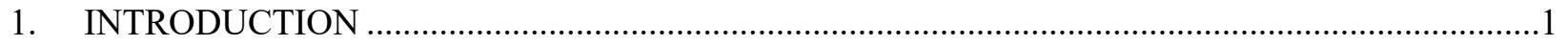

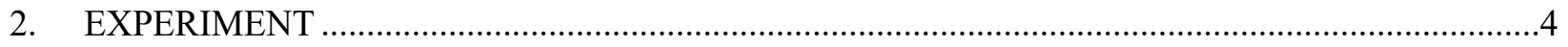

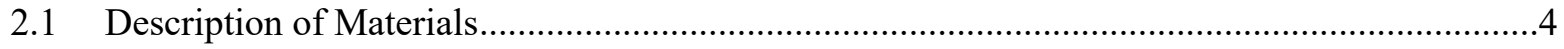

2.2 X-Ray Radiography of Paris-Edinburgh (PE) Cell Compression Testing .................................5

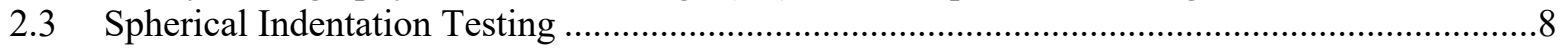

2.4 Double Toroid Diamond Anvil Cell (DTDAC) Compression Testing ....................................11

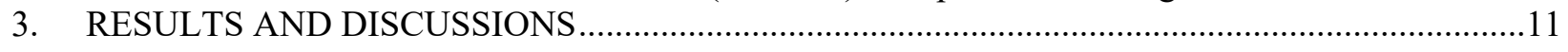

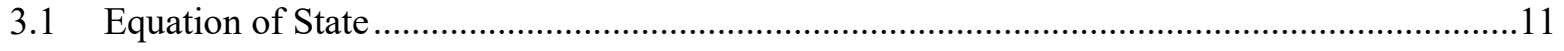

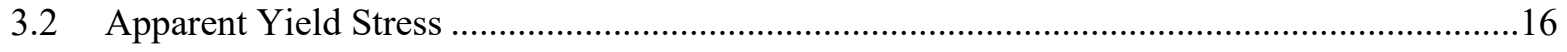

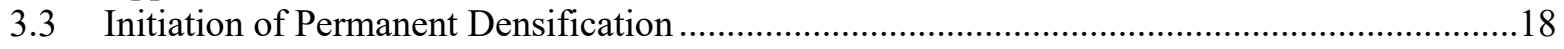

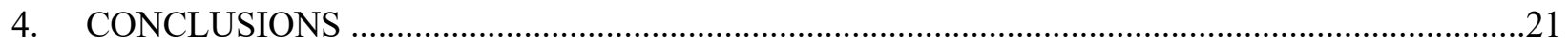

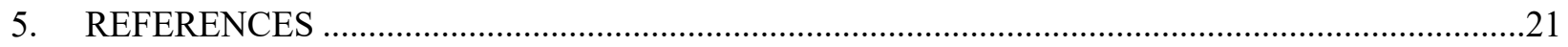





\section{LIST OF FIGURES}

Figure 1. Density change of various glasses as a function hydrostatic pressure [1] .............................2

Figure 2. Location of the amorphous diffraction peak (d-spacing changes) from X-ray

diffraction in fused quartz as a function of pressure in diamond anvil cell testing. An

inflection occurs around $10 \mathrm{GPa}$; however, the confidence in that value is low due to

experimental uncertainty associated with the reported d-spacing value.

Figure 3. Location of the amorphous diffraction peak (d-spacing changes) from X-ray

diffraction of Starphire ${ }^{\circledR}$ as a function of pressure in diamond anvil cell testing. An

inflection occurs around $5 \mathrm{GPa}$; however, like in Fig. 2, the confidence in that value

is low due to experimental uncertainty associated with the reported d-spacing value.

Figure 4. Location of the amorphous diffraction peak (d-spacing changes) from X-ray

diffraction in a BOROFLOAT ${ }^{\mathbb{B}}$ as a function of pressure in diamond anvil cell

testing. Confidence bounds on $\mathrm{d}$-spacing aid the identification of the inflection

stress, but not conclusively.

Figure 5. Schematic of the Paris-Edinburgh Cell showing the sample arrangement and the gold

foil around the sample to serve as sample boundaries in volume determination by $\mathrm{x}-$

ray radiography.

Figure 6. A) A cropped radiograph for copper at $0.53 \mathrm{GPa}$. The red line indicates channel $\mathrm{x}=$ $350 \mathrm{px}$ where the line intensity profile is taken. B) The brightness at each pixel plotted for channel $x=350 \mathrm{px}$. C) The first derivative of the brightness along channel $\mathrm{x}=350$, this shows where the edges of the sample are.

Figure 7. Copper initial ambient $(0.1 \mathrm{GPa})$ and highest-pressure energy dispersive X-ray diffraction spectrum $(11.5 \mathrm{GPa})$ with HKL indices denoted. The diffraction angle $2 \theta$ $=15.01285^{\circ}$.

Figure 8. The results of the validation experiment on copper. The open circles are the volume measured by radiography and pressure measured by the copper pressure standard. The solid curve is the fitted equation of state to the radiography data with bulk modulus $\mathrm{B}_{0}=143.7 \mathrm{GPa}$ and pressure derivative of bulk modulus $\mathrm{B}_{0}{ }^{\prime}=3.904$.

Figure 9. Zwick indenter used for spherical indentation testing. . .8

Figure 10. Spherical indentation stress field [13], image of tile being indented, and a schematic of the indenter depth of penetration sensor.

Figure 11. Examples of indentation load as a function of indenter penetration generated with the Zwick micro-indentation system shown in Figs. 9-10. This system generates similar output to a nanoindenter but applies several orders of magnitude higher loads.

Figure 12. Double toroid diamond anvil cell tests a specimen that is similarly sized to a baby aspirin. Its large test specimen size provides a relatively large volume of tested material for postmortem structural characterization of high-pressure-loaded glass. ................11

Figure 13. BOROFLOAT ${ }^{\circledR}$ radiography images used for Birch-Murnaghan equation of state fit............12

Figure 14. Starphire ${ }^{\circledR}$ radiography images used for Birch-Murnaghan equation of state fit. ...................13

Figure 15. Fused quartz radiography images used for Birch-Murnaghan equation of state fit. ................14

Figure 16. Recovered BOROFLOAT ${ }^{\circledR}$ sample $(1.0 \mathrm{~mm}$ height and $1.0 \mathrm{~mm}$ diameter $)$ after pressurization to $4.7 \mathrm{GPa}$. 25X magnification.

Figure 17. Recovered Starphire ${ }^{\circledR}$ sample (1 mm diameter, $0.5 \mathrm{~mm}$ height) after pressurization to 11.8 GPa. 25X magnification.

Figure 18. Recovered fused quartz sample ( $1 \mathrm{~mm}$ diameter, $0.5 \mathrm{~mm}$ height) after pressurization to $11.8 \mathrm{GPa}$. 25X magnification.

Figure 19. Spherical indentation response can provide a point on the Pressure-Equivalent Stress yield surface......

Figure 20. Float densification was used to characterize permanent density changes [15].... .18 
Figure 21. Density as a function of DTDAC sample pressure for BOROFLOAT ${ }^{\circledR}$

Figure 22. Density as a function of DTDAC sample pressure for Starphire ${ }^{\circledR}$........................................19

Figure 23. FEA model used to examine the multiaxial stress state in a DTDAC specimen. ...................20

Figure 24. The superimposed shear and hydrostatic pressure of the DTDAC is an illustration of why its specimen is designated as having "quasi-hydrostatic" stress state.

\section{LIST OF TABLES}

Table 1. Weight percentages of constituents in the evaluated vitreous silicates [2] .............................5

Table 2. Bulk Modulus $\left(B_{0}\right)$ and first derivative of bulk modulus with respect to pressure $\left(B_{0}{ }_{0}\right) \ldots \ldots \ldots . . .14$

Table 3. Comparison of initial and final densities from the PE anvil testing.....................................16

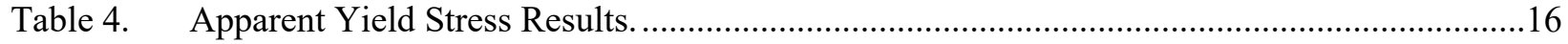





\section{ACKNOWLEDGMENTS}

This research was performed at the Oak Ridge National Laboratory (ORNL) under the Material Science and Technology Division and sponsored by the US Army Tank Automotive Research Development and Engineering Center (TARDEC), DOE Strategic Partnership Projects (SPP) Program, IAN: 43WZ15901, and DOE Project No. 1969-Z159-17 with the U.S. Department of Energy. The authors thank US Army TARDEC's T. Talladay for financial support, US Army Research Laboratory's P. Patel for technical support, and ORNL's J. Molaison for use of the SNS DTDAC facility, R. Parten for specimen fabrication, T. Geer for metallography, and J. Molaison, R. Robertson, and E. Lara-Curzio for reviewing the manuscript.

\section{DISCLAIMER}

Reference herein to any specific commercial company, product, process, or service by trade name, trademark, manufacturer, or otherwise, does not necessarily constitute or imply its endorsement, recommendation, or favoring by the United States Government or the Department of the Army (DoA). The opinions of the authors expressed herein do not necessarily state or reflect those of the United States Government or the DoA, and shall not be used for advertising or product endorsement purposes. 



\begin{abstract}
The improved understanding of the high-pressure response of vitreous silicates is relevant to sought-after improvements of transparent protective systems. In this study, the quasi-static high-pressure ( $>1 \mathrm{GPa})$ mechanical responses of BOROFLOAT ${ }^{\circledR}$ and Starphire $^{\circledR}$ vitreous silicates were examined using three methods. The first combined $\mathrm{x}$-ray radiography with compression testing in a Paris-Edinburgh anvil at the Advanced Photon Source at Argonne National Laboratory, and is a method recently developed at the University of Alabama at Birmingham. An outcome of that testing is the portrayal of volume change as a function of (quasi) hydrostatic pressure or its equation of state. The second employed method was spherical indentation and is one that can be used to identify the onset of permanent deformation in brittle materials. The outcome of that testing is the estimation of an apparent yield stress. The last method involved the use of a double-toroid diamond anvil cell to compress a specimen. This test method subjects a relatively large volume of material to a quasi hydrostatic stress and whose volume enables material postmortem analysis. An outcome of that testing, when coupled with precision density measurements, is the identification of the apparent hydrostatic pressure when permanent densification initiates. The three test methods and results from the testing of BOROFLOAT ${ }^{\circledR}$ and Starphire ${ }^{\circledR}$ vitreous silicates are presented.
\end{abstract}

\title{
1. INTRODUCTION
}

The permanent deformation of (brittle) vitreous silicates when subjected to large compressive stresses or pressure (i.e., stresses greater than $1 \mathrm{GPa}$ or $10 \mathrm{kbar}$ ) can occur via fracture and cracking, or a shear-like or viscous-like response, or densification, or often a combination thereof. A material's equation of state (EOS) describes the resulting volume change when it is subjected to pressure (i.e., $\mathrm{V}=f(\mathrm{P})$ ), specifically, hydrostatic pressure. The onset of densification in a vitreous silicate and its progression as pressure increases is described by its EOS.

Vitreous silicates and amorphous non-silicates too can significantly densify if subjected to a sufficiently high pressure, as illustrated in Fig. 1 [1]. High purity $\mathrm{SiO}_{2}$, referred to as either fused silica or fused quartz*, are known to undergo upwards of a $20 \%$ density increase upon decompression. Other vitreous silicates such as BOROFLOAT ${ }^{\circledR}$ and Starphire ${ }^{\circledR}$ are attractive for use in transparent protective systems and their comparison has been of interest for several years [2-3]; however, their densification behavior (and their EOS's) are less characterized and understood.

\footnotetext{
* Fused silica and fused quartz, while stoichiometrically equivalent versions of high-purity vitreous $\mathrm{SiO}_{2}$, are fabricated by two different methods that result in fused silica having orders of magnitude more water content at the molecular scale, and therefore are not identical materials.
} 


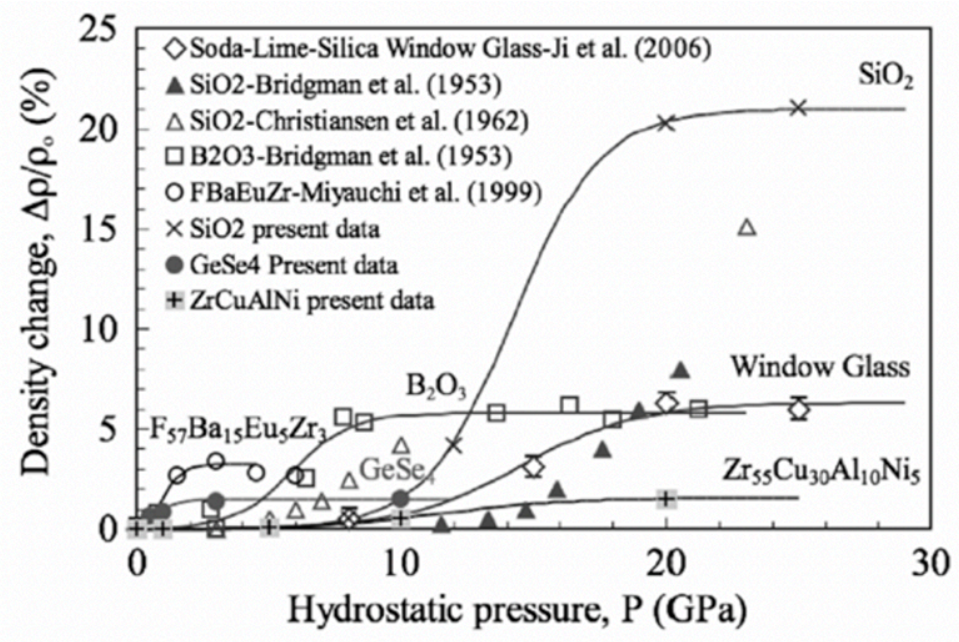

Figure 1. Density change of various glasses as a function hydrostatic pressure [1].

If a material is polycrystalline, then a common method to estimate its EOS is to subject a sample to high pressure in a diamond anvil cell or Paris-Edinburgh (PE) anvil while concurrently tracking responding changes in x-ray diffraction peaks. The facilities at the Advanced Photon Source (APS) at Argonne National Laboratory were sought for such measurements. Quantifiable shifts in the x-ray diffraction peaks can be used to estimate volume change in the polycrystalline material.

But if the material is vitreous or amorphous, then sharp and definable x-ray diffraction peaks do not result, and interpretation of responding shifts of an "amorphous hump" due to applied pressure introduces uncertainty. For example, such testing was used in the present study with fused quartz, Starphire ${ }^{\mathbb{R}}$, and BOROFLOAT $^{\circledR}$ to track X-ray diffraction d-spacing as a function of applied pressure as shown in Figs. 24 , respectively. However, the uncertainty associated with the choice of a d-spacing value is either an unknown (see Figs. 2-3) or is relatively large if it could be estimated (Fig. 4), so there is concomitant uncertainty in identifying the pressure where a change of some kind appears to be occurring.

To address this issue with vitreous silicates, the University of Alabama at Birmingham (UAB) developed a method that combines X-ray radiography with PE anvil testing [4-5] at the APS, whereby the change in volume of a pressurized sample is tracked with captured radiographs and image analysis. Interpretation of those images and applied pressure enables the construction of an estimated EOS of an amorphous material. This study utilizes this method to construct the EOS of BOROFLOAT ${ }^{\circledR}$ and Starphire ${ }^{\circledR}$ vitreous silicates.

But each vitreous silicate's EOS is likely to be affected by factors such as superimposed shear and densification and perhaps even by different contributions from each. Spherical indentation is a test method that superimposes both shear and hydrostatic pressure into a test specimen, so it was used to supplement the EOS estimations for the vitreous silicates and aid in the overall interpretation of the high-pressure responses. Regarding the examination of permanent densification, particularly its onset, a double toroid diamond anvil cell (DTDAC) [6] was used to impose quasi hydrostatic stress into relatively large DTDAC test specimens (equivalent in shape and size to a baby aspirin), and specimens were tested to different maximum stresses. The density of the tested specimens was then measured using a precision float method whose liquids have known specific gravities. The interpretation of these responses was also aimed to supplement the EOS estimates. 


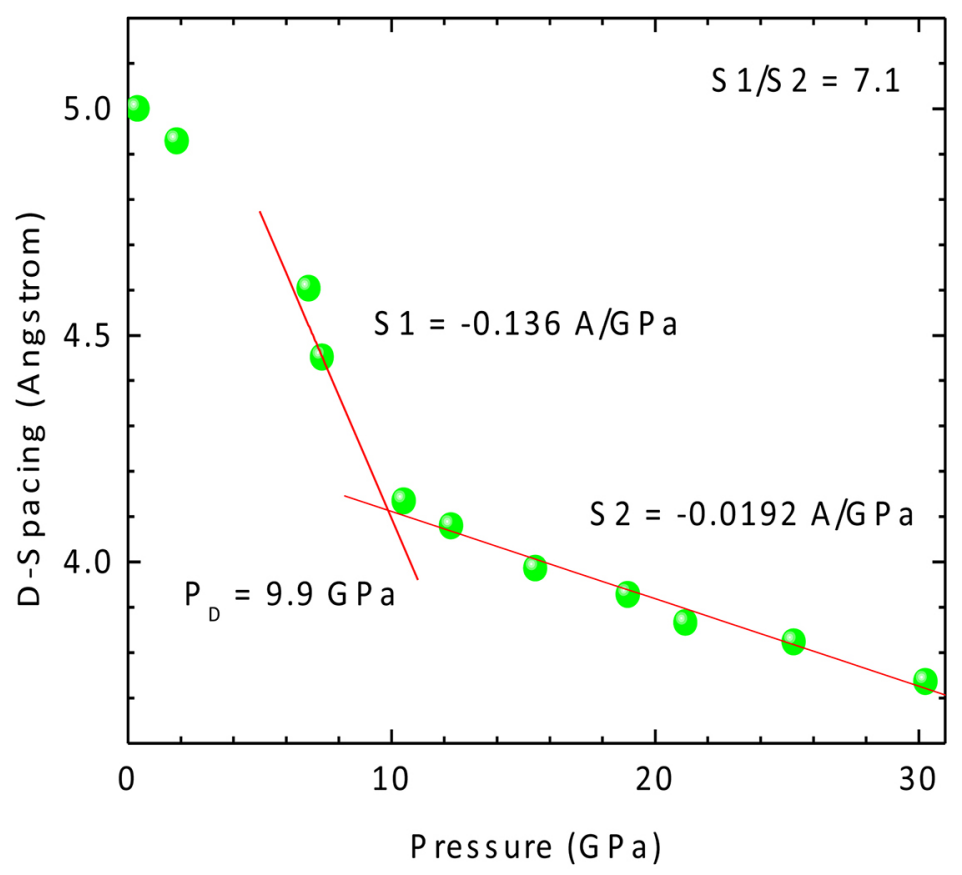

Figure 2. Location of the amorphous diffraction peak (d-spacing changes) from X-ray diffraction in fused quartz as a function of pressure in diamond anvil cell testing. An inflection occurs around 10 GPa; however, the confidence in that value is low due to experimental uncertainty associated with the reported d-spacing value.

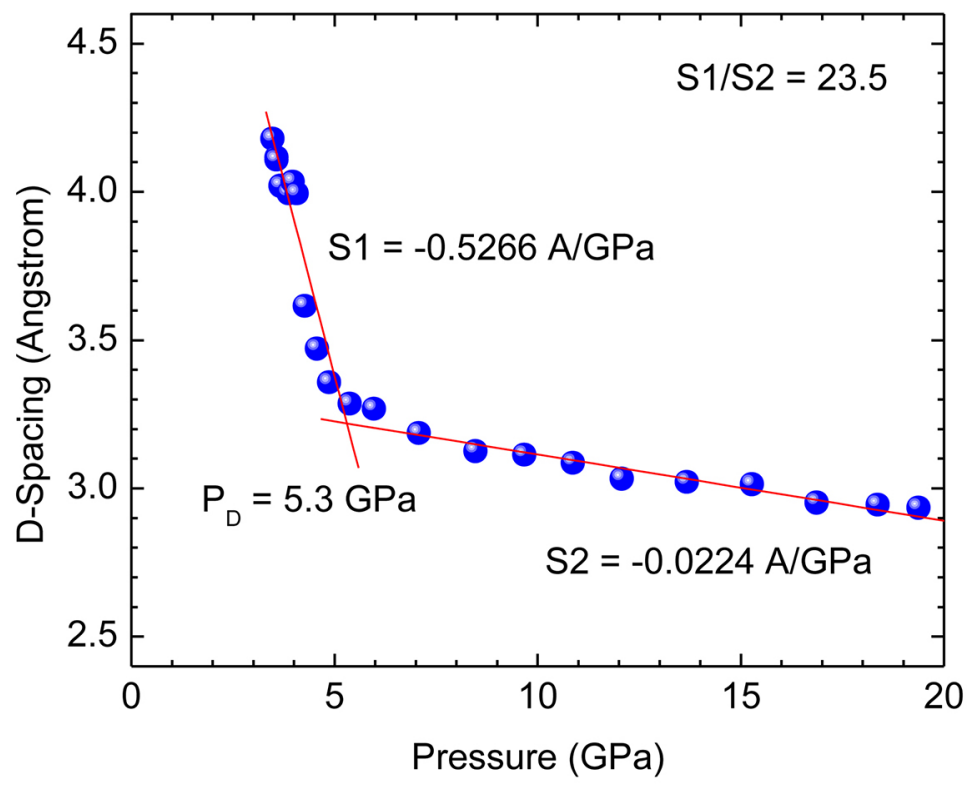

Figure 3. Location of the amorphous diffraction peak (d-spacing changes) from X-ray diffraction of Starphire ${ }^{\circledR}$ as a function of pressure in diamond anvil cell testing. An inflection occurs around 5 GPa; however, like in Fig. 2, the confidence in that value is low due to experimental uncertainty associated with the reported d-spacing value. 


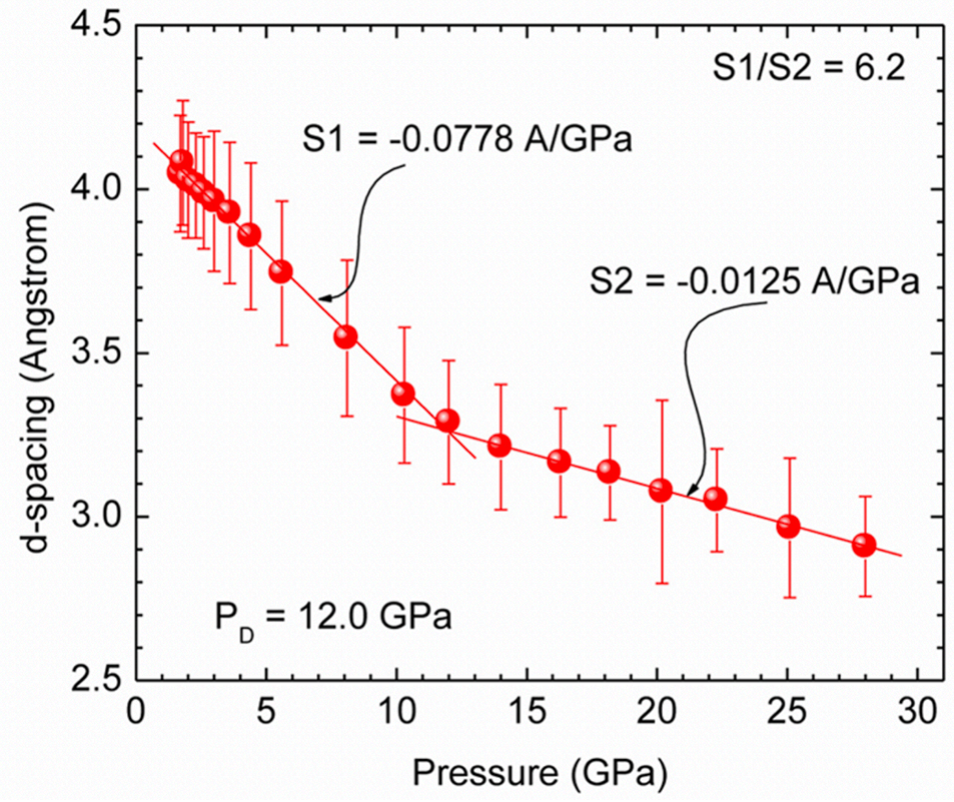

Figure 4. Location of the amorphous diffraction peak (d-spacing changes) from X-ray diffraction in a BOROFLOAT $^{\circledR}$ as a function of pressure in diamond anvil cell testing. Confidence bounds on d-spacing aid the identification of the inflection stress, but not conclusively.

\section{EXPERIMENT}

Vitreous silicates were subjected to PE anvil compression testing, spherical indentation, and DTDAC compression testing. The focus was on the testing of BOROFLOAT ${ }^{\circledR} 33$ (or also referred to in this report as just BOROFLOAT ${ }^{\circledR}$ ) borosilicate and Starphire ${ }^{\circledR}$ soda-lime silicate glasses; however, fused quartz was also tested in some circumstances and its response served as a reference.

\subsection{Description of Materials}

The chemistries of the tested vitreous silicates are listed in Table 1. BOROFLOAT ${ }^{\circledR} 33$, Starphire ${ }^{\circledR}$, and the fused quartz were fabricated by SCHOTT North America, Vitro Glass, and Momentive, respectively. 
Table 1. Weight percentages of constituents in the evaluated vitreous silicates [2].

\begin{tabular}{|c|c|c|c|}
\hline Constituent & BOROFLOAT $^{\circledR}$ 33 & Starphire $^{\circledR}$ & Fused Quartz $^{\circledR}$ \\
\hline $\mathrm{SiO}_{2}$ & 80.54 & 73.23 & 100 \\
\hline $\mathrm{B}_{2} \mathrm{O}_{3}$ & 12.70 & & \\
\hline $\mathrm{Al}_{2} \mathrm{O}_{3}$ & 2.53 & 1.45 & \\
\hline $\mathrm{Na}_{2} \mathrm{O}$ & 3.53 & 14.71 & \\
\hline $\mathrm{K}_{2} \mathrm{O}$ & 0.64 & 0.01 & \\
\hline $\mathrm{CaO}$ & 0.02 & 10.28 & \\
\hline $\mathrm{MgO}$ & & 0.08 & \\
\hline $\mathrm{SrO}$ & & 0.20 & \\
\hline $\mathrm{ZrO}$ & 0.03 & 0.03 & 100 \\
\hline $\mathrm{Total}$ & 100 & 100 & \\
\hline
\end{tabular}

Different specimen geometries were prepared for each of the three tests. Small disks were used for the PE cell compression testing, plates polished in oil-based media [7] were used for the spherical indentation, and DTDAC specimens (resembling a baby aspirin geometry and of about the same size) were used for the DTDAC compression testing.

\subsection{X-Ray Radiography of Paris-Edinburgh (PE) Cell Compression Testing}

White-beam X-ray radiography studies were conducted at Beamline 16-BM-B, HPCAT, The Advanced Photon Source, Argonne National Laboratory, Chicago, IL. One sample from each of the three vitreous silicates in Table 1, and one copper sample were tested.

All samples were quasi-hydrostatically compressed at ambient temperature using a Paris-Edinburgh (PE) cell. The cell assembly, shown in Fig. 5, consists of a cylindrical sample housed within a hexagonal boron nitride $(\mathrm{h}-\mathrm{BN})$ cup with a $\mathrm{h}-\mathrm{BN}$ cap, which is surrounded by a magnesium oxide $(\mathrm{MgO})$ inner ring and a boron epoxy outer ring, which is all surrounded by supporting outer polycarbonate plastic (Lexan) ring. This setup is sandwiched between zirconium oxide $\left(\mathrm{ZrO}_{2}\right)$ caps, which are shaped to match the PE anvil geometry. The detector angle was calibrated from the known lattice parameter of gold ( $\mathrm{Au}$ ) at ambient pressure and utilizing the following diffraction peaks from gold (111), (200), (220), (311), (222), (400), (331), (420), (422), (333), (531), (422), and (620). The diffraction angle was calibrated to be $2 \theta=15.01285$ $\pm 0.00258^{\circ}$.

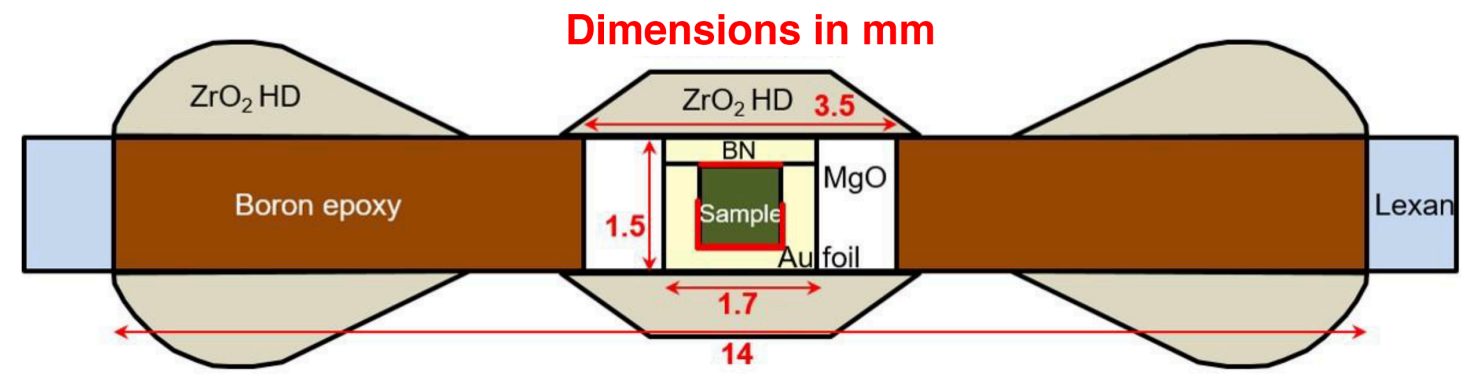

Figure 5. Schematic of the Paris-Edinburgh Cell showing the sample arrangement and the gold foil around the sample to serve as sample boundaries in volume determination by $x$-ray radiography. 
Gold foil (shown in red surrounding the sample in Fig. 5) was used as the pressure reference and the marker in the white-beam X-ray radiography direct volume measurement. Two separate pieces of gold foil were used, one on top of the sample and one longer piece that fit underneath of the sample in a "U shape", to directly measure the changing sample height and width with increasing pressure. In between each white-beam X-ray radiography measurement an energy-dispersive X-ray diffraction (EDXD) spectrum was taken of the top gold foil at $2 \theta=15.01285^{\circ}$ to determine pressure. The (220), (311), (400), (331), (420), and (333) Miller indices (hkl) were indexed for gold foil (space group $F \mathrm{~m} \overline{3} \mathrm{~m}$ (number 225)) to determine the lattice parameter $a$ in order to obtain the volume $\mathrm{V}$. This volume was used with bulk modulus $B_{0}=165.8 \mathrm{GPa}$, first derivative of the bulk modulus $B_{0}^{\prime}=5.14$, and initial volume $V_{0}=67.850 \AA^{3}$ (at ambient conditions) to obtain the sample pressure using the third-order Birch-Murnaghan equation of state [8-9].

$$
\begin{gathered}
\lambda=2 d \sin \theta \\
E=\frac{h c}{\lambda}=\frac{h c}{2 d \sin \theta} \therefore d=\frac{h c}{2 E \mid \sin \theta} \\
\frac{1}{d^{2}}=\frac{h^{2}+k^{2}+l^{2}}{a^{2}} \therefore a=d \sqrt{h^{2}+k^{2}+l^{2}} \\
V(V)=\frac{3}{2} B_{0}\left[\left(\frac{V_{0}}{V}\right)^{\frac{7}{3}}-\left(\frac{V_{0}}{V}\right)^{\frac{5}{3}}\right]\left\{1+\frac{3}{2}\left(B_{0}^{\prime}-4\right)\left[\left(\frac{V_{0}}{V}\right)^{\frac{2}{3}}-1\right]\right\} \\
B_{0}=-V\left(\frac{\partial P}{\partial V}\right)_{P=0} \\
B_{0}^{\prime}=\left(\frac{\partial B}{\partial P}\right)_{P=0}
\end{gathered}
$$

The radiographs collected at each pressure step were 1936 pixels $(\mathrm{px}) \times 1216 \mathrm{px}$ with a resolution of $0.85 \mu \mathrm{m} / \mathrm{px}$. Radiography bulk volume analysis was conducted with MATLAB R2017b. Each radiograph had 200-line intensity profiles of the sample intensity taken for both the width and 1000-line intensity profiles of the sample taken for the height. The copper sample with a dark line indicating channel $\mathrm{x}=350$ is shown in Fig. 6A. The intensity was found for each pixel and a line intensity map was found for each individual channel. The brightness scanned from pixel 1 to pixel 651 at $x=350 \mathrm{px}$ is shown in Fig. $6 \mathrm{~B}$, where the light portion outside of the bulk metallic glass sample is the $\mathrm{MgO}$ and the extent of the sample is the dark square (Fig. 6A). The raw brightness data is smoothed with a moving average method with a span of 0.3 . To determine the edges of the sample along each line the derivative, $\mathrm{d}$ (brightness)/d(pixel) was taken and a Gaussian fit was applied to the two peaks (Fig. 6C). The parameters $b 1$ and $b 2$, which are the Gaussian peak centers, can be used to determine the width along one channel. An average is taken from all of fits to determine the length of side 1 and side 2 . From this the volume is calculated as $V=\pi \mathrm{H}(\mathrm{W} / 2)^{2}$, where $W$ is the width of the sample and $H$ is the height of the sample. 

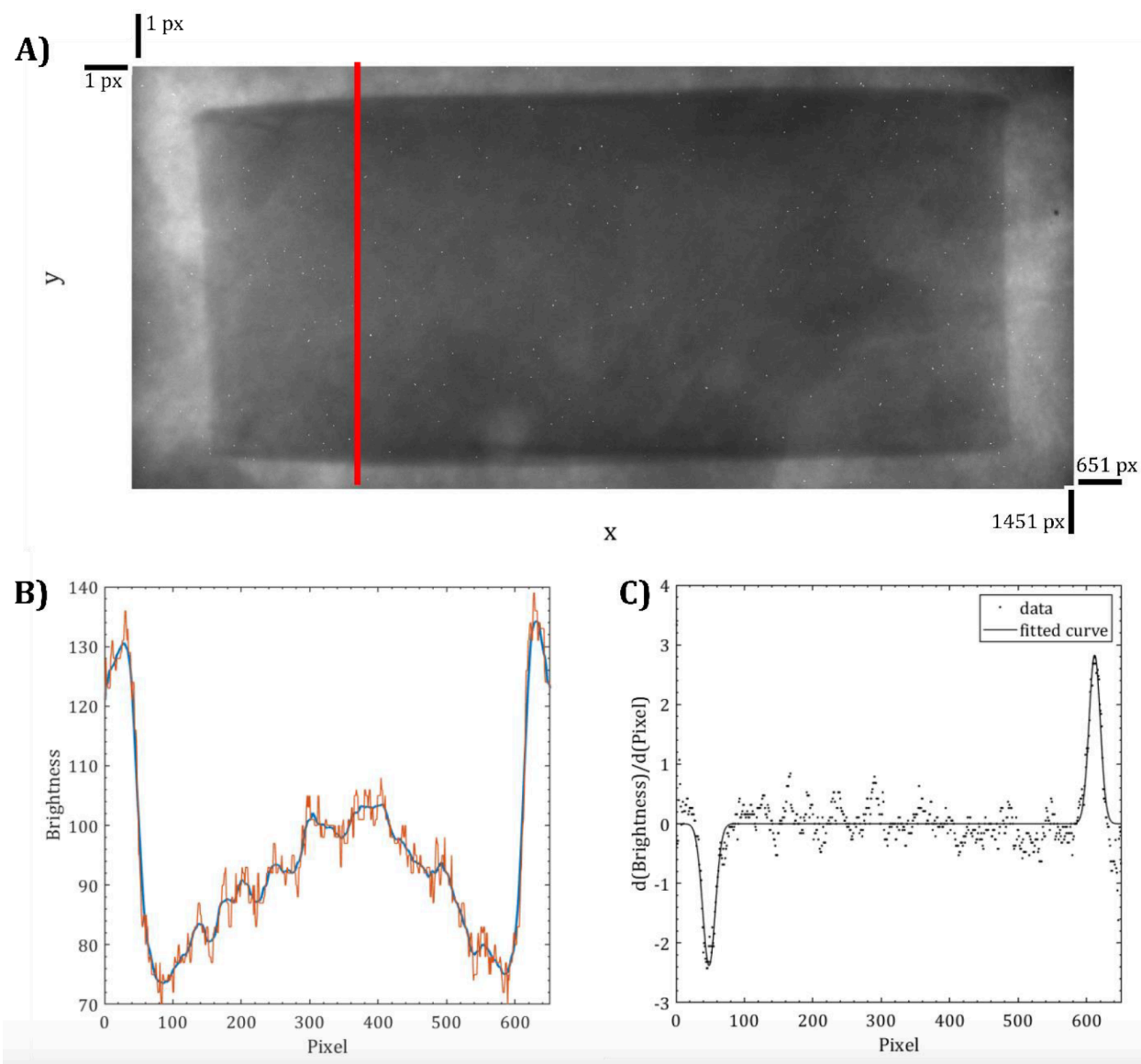

Figure 6. A) A cropped radiograph for copper at $0.53 \mathrm{GPa}$. The red line indicates channel $\mathrm{x}=350 \mathrm{px}$ where the line intensity profile is taken. B) The brightness at each pixel plotted for channel $x=350$ px. C) The first derivative of the brightness along channel $x=350$, this shows where the edges of the sample are.

A proof of concept experiment was conducted on a cylindrical sample of $\mathrm{Cu}$ from ambient condition to a maximum pressure of $10.1 \mathrm{GPa}$. Radiography images were taken at increasing pressure steps, and the sample was decompressed from $10.1 \mathrm{GPa}$ to ambient conditions. White-beam energy-dispersive X-ray diffraction was also collected for copper, with Miller indices: 220, 311, 400, 331, 420, 422, 511, 333, 440, 531, 442, 620 used to obtain the volume. Copper has a face-centered cubic structure with space group number $225, F m \overline{3} m$ at ambient conditions [10]. The energy dispersive pattern from copper at ambient and high pressures is shown in Fig. 7.

The measured EOS of copper by radiography using the pressure determined from the copper pressure standard is shown in Fig. 8. The solid curve is the fit to the data using the Birch Murnaghan equation of state with $\mathrm{B}_{0}=143.7 \mathrm{GPa}$ and pressure derivative $\mathrm{B}_{0}{ }^{\prime}=3.904$. It should be added that the fitted values to radiography data compare favorably with literature value of $\mathrm{B}_{0}=140 \mathrm{GPa}$ and pressure derivative $\mathrm{B}_{0}{ }^{\prime}=4[10]$. 


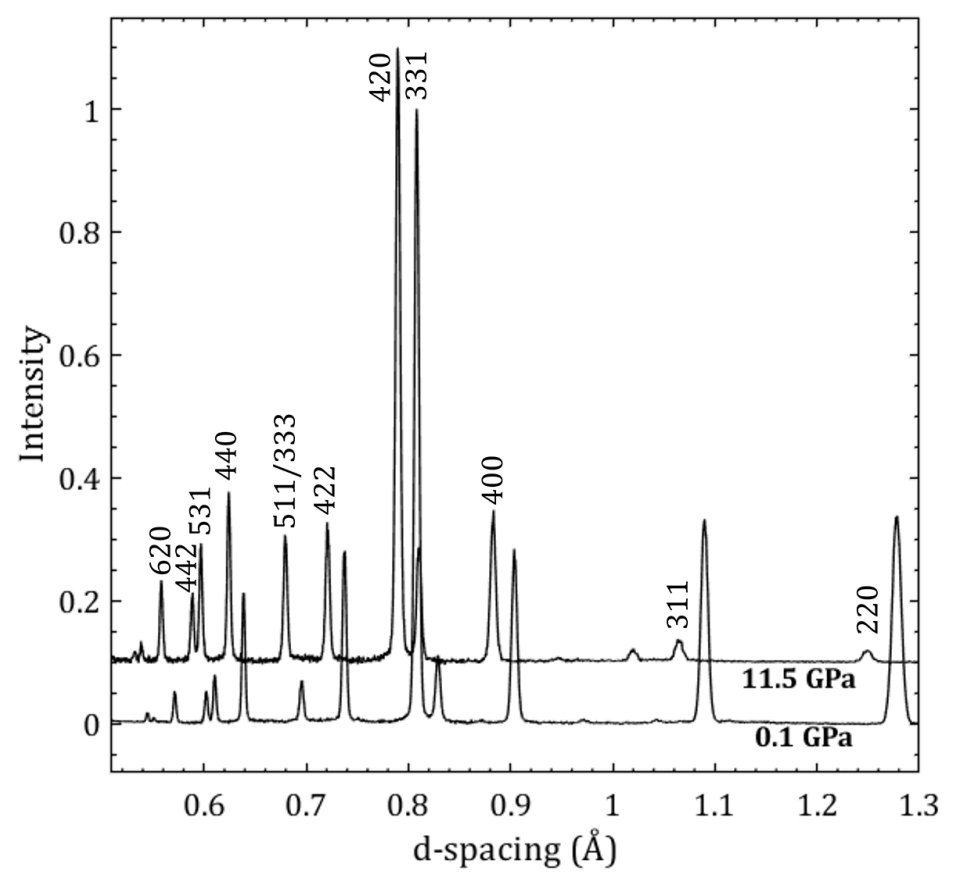

Figure 7. Copper initial ambient (0.1 GPa) and highest-pressure energy dispersive X-ray diffraction spectrum $(11.5 \mathrm{GPa})$ with HKL indices denoted. The diffraction angle $2 \theta=15.01285^{\circ}$.

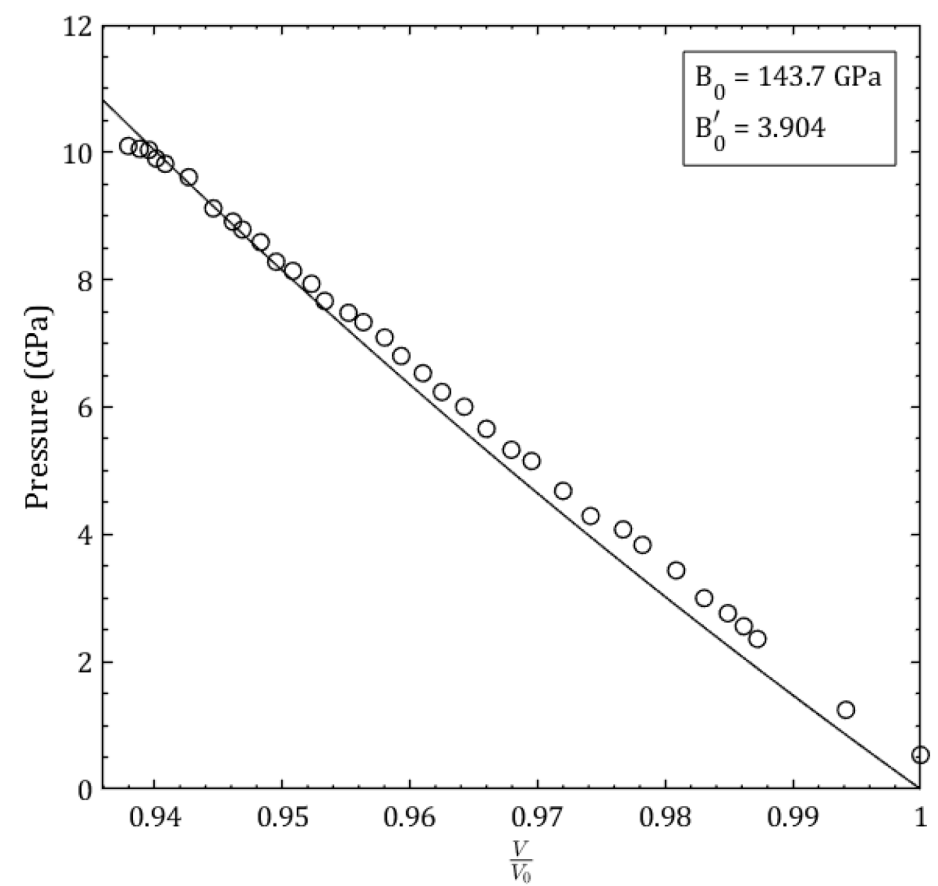

Figure 8. The results of the validation experiment on copper. The open circles are the volume measured by radiography and pressure measured by the copper pressure standard. The solid curve is the fitted equation of state to the radiography data with bulk modulus $B_{0}=143.7 \mathrm{GPa}$ and pressure derivative of bulk modulus $B_{0}$, = 3.904.Spherical Indentation Testing

A Zwick microhardness tester was used for the spherical indentation testing. Its system is shown in Fig. 9. The produced stress state (under elastic conditions) and a description of the indenter depth-of-penetration 
(IDOP) are shown in Fig. 10. Examples of the measured loading-unloading response of spherical indentation are shown in Fig. 11. For the same applied force, a material with a lower elastic modulus will undergo a greater amount of IDOP; that is the case for BOROFLOAT ${ }^{\circledR}$ as it has a lower elastic modulus than both fused quartz and Starphire ${ }^{\circledR}$.

The measured loading response is interpreted and the applied force where the onset of yield occurs is identified [11-12]. Using that identified force, the apparent yield stress of the material is calculated using classical Hertz theory. The adjective "apparent" is purposely used because surface-detection of a permanent dimple is used to identify an associated force; however, initiation of permanent deformation can occur in the sub-surface where shear is a maximum, so the (actual) yield stress is slightly lower than the apparent yield stress because additional applied force is required to transition that sub-surface permanent damage to the surface (when it is finally detected).

Spherical indentation was additionally performed on BOROFLOAT ${ }^{\circledR}$ and Starphire $^{\circledR}$ using a nanoindenter [12], and its results are included for the sake of comparison.

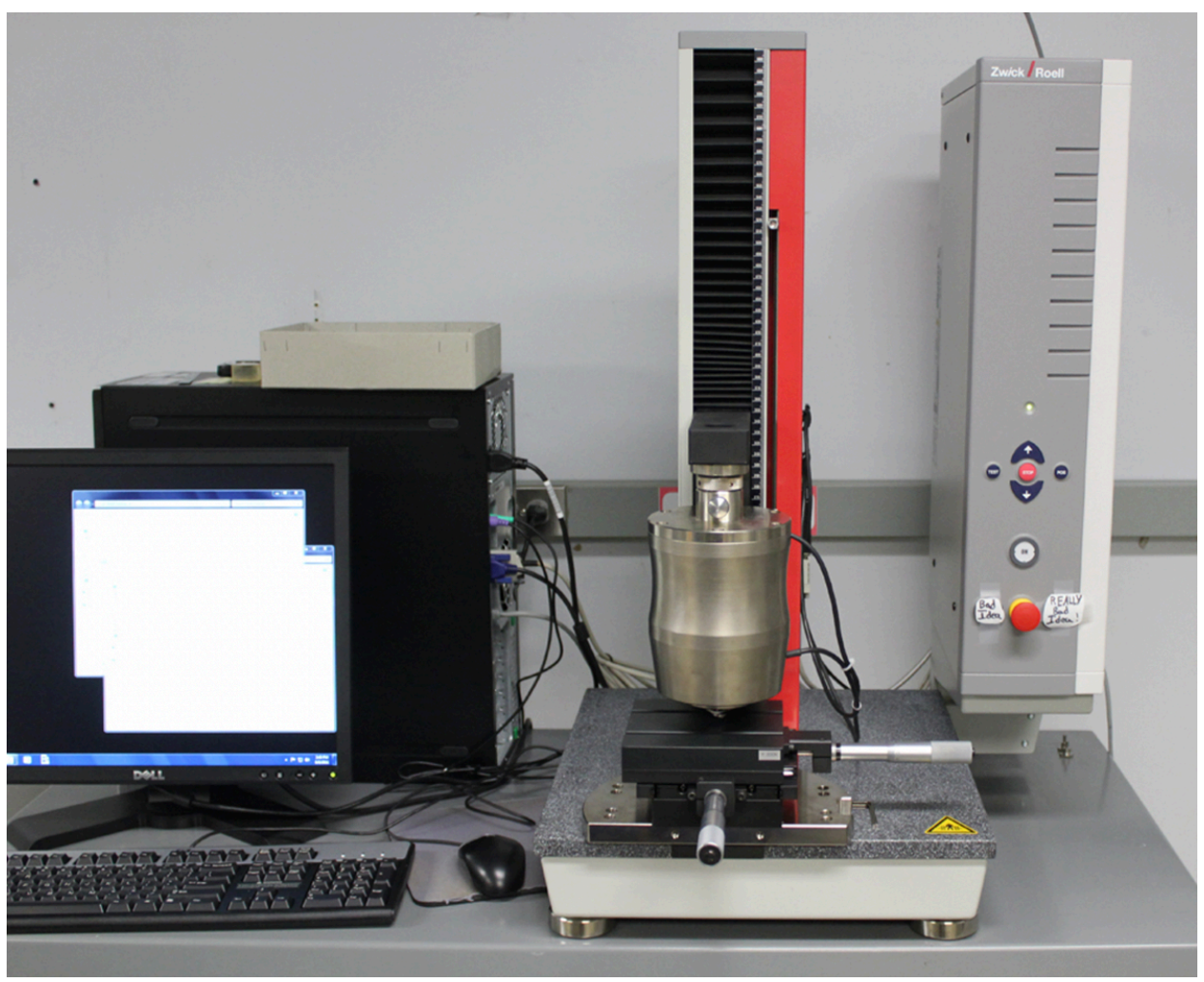

Figure 9. Zwick indenter used for spherical indentation testing. 


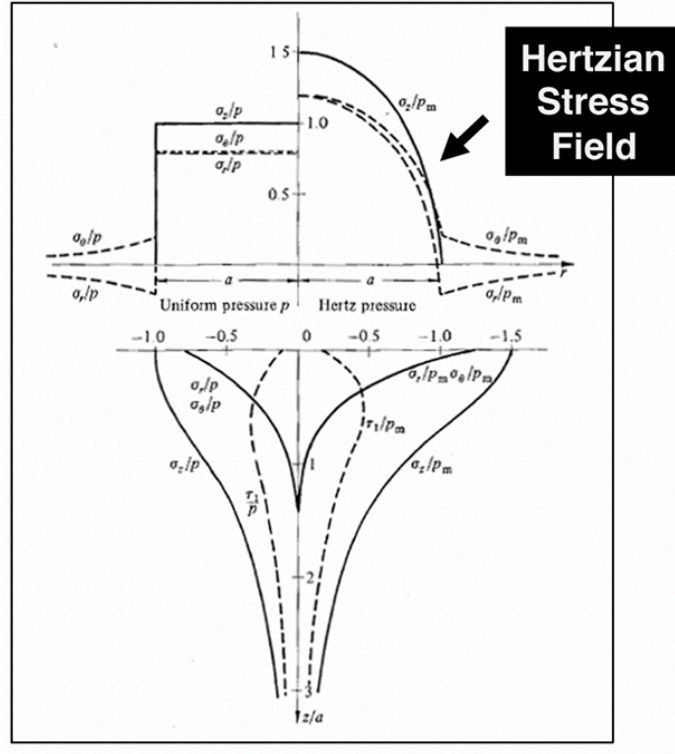

Johnson, Contact Mechanics, 1985
Load (up to $200 \mathrm{~N}$ ) and Indenter Depth-of-Penetration Measured
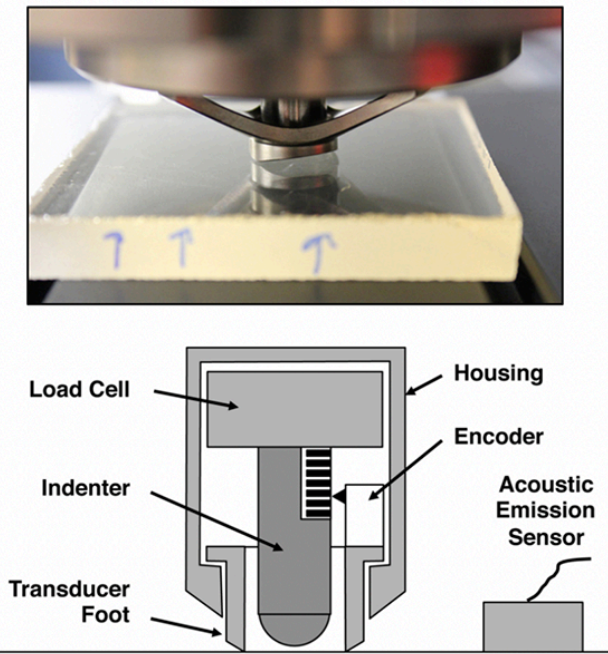

Test Sample

Figure 10. Spherical indentation stress field [13], image of tile being indented, and a schematic of the indenter depth of penetration sensor.

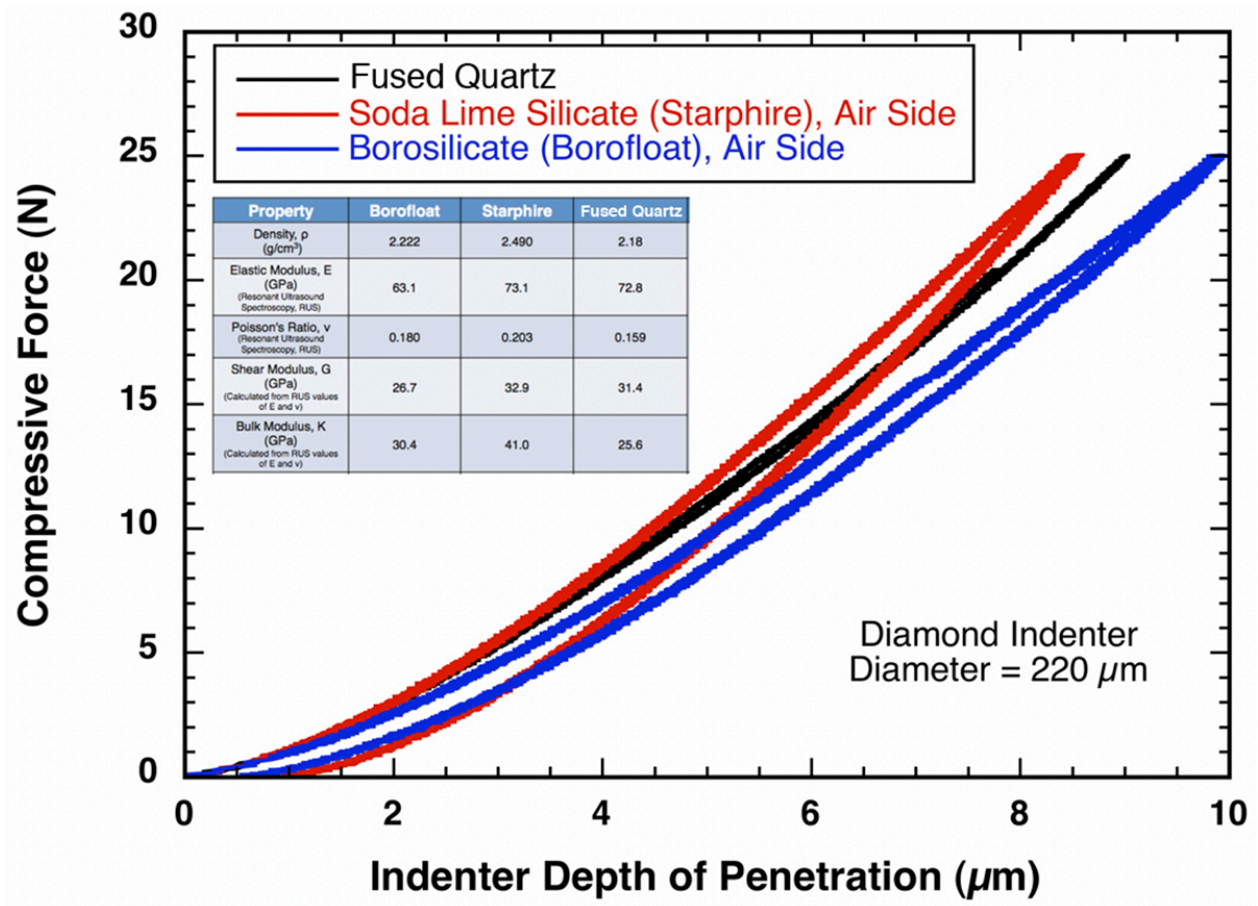

Figure 11. Examples of indentation load as a function of indenter penetration generated with the Zwick microindentation system shown in Figs. 9-10. This system generates similar output to a nanoindenter but applies several orders of magnitude higher loads. 


\subsection{Double Toroid Diamond Anvil Cell (DTDAC) Compression Testing}

The onset of densification for Borofloat ${ }^{\circledR}$ and Starphire ${ }^{\circledR}$ were examined using a combination of DTDAC compression testing and high-precision density measurements of the post-tested specimens. A schematic of the test cell and the associated specimens are shown in Fig. 12. Specimen density was measured as a function of maximum (quasi) hydrostatic pressure using a flotation method with a high-specific-gravity liquid. Lithium metatungstate, a commercially available liquid whose specific gravity (SG) is 2.95 , and which is aqueous-based, was diluted with water to custom produce lower SG's that matched the density of each glass sample.
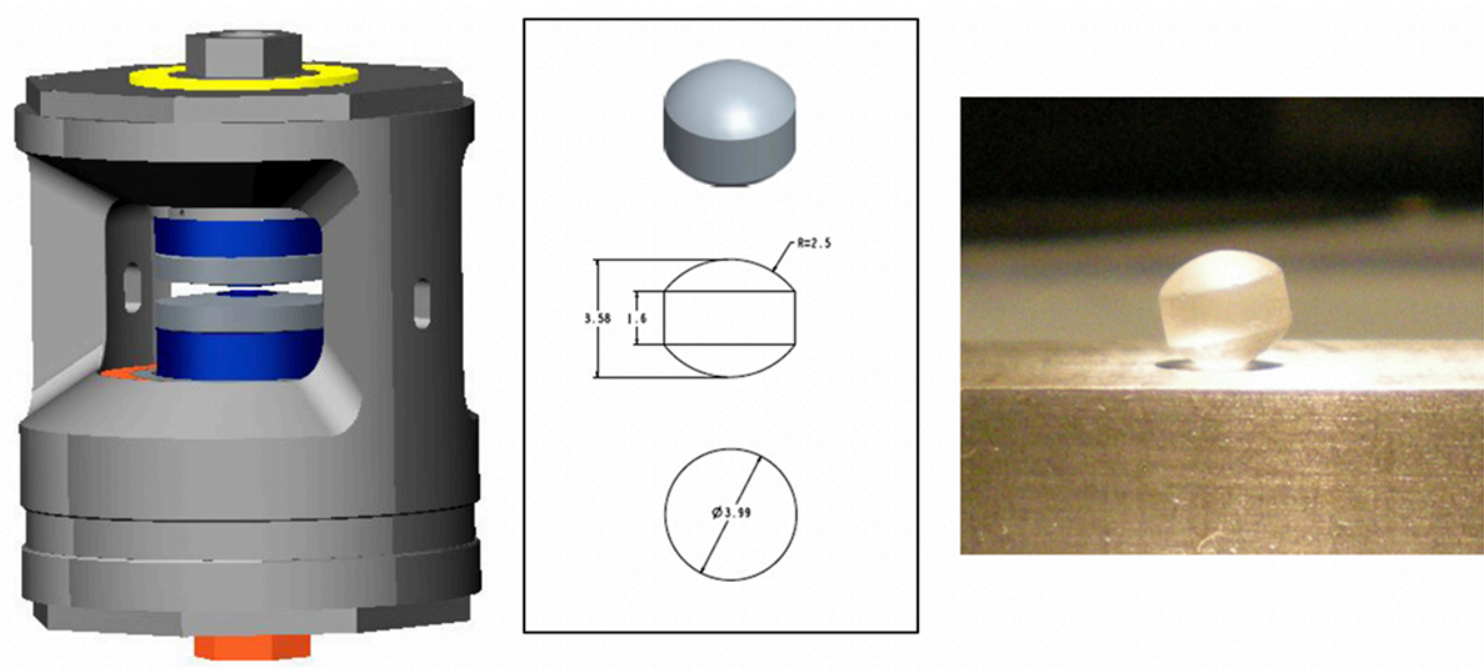

Figure 12. Double toroid diamond anvil cell tests a specimen that is similarly sized to a baby aspirin. Its large test specimen size provides a relatively large volume of tested material for postmortem structural characterization of high-pressure-loaded glass.

\section{RESULTS AND DISCUSSIONS}

The results from the PE anvil, spherical indentation, and DTDAC testing are presented as Equation of State, apparent yield stress, and initiation of densification, respectively.

\subsection{Equation of State}

Given the good correlation of the EOS's parameters with the copper sample, the testing proceeded with the three vitreous silicates. The estimated $\mathrm{B}_{0}$ and $\mathrm{B}_{0}$ ' for the BOROFLOAT ${ }^{\circledR}$, Starphire, and fused quartz samples are shown in Figs. 13-15, respectively, and their summarized fitting parameters are listed in Table 2. The estimations of the $\mathrm{B}_{0}$ using the radiography method correlates well with its measurement from other methods.

Postmortem analysis of the test specimens, images of each shown in Figs. 16-18, consisted of estimating the post-testing density using floatation method and radiography, and comparing it with its pre-testing density. The amount of permanent densification is summarized in Table 3 . The estimated density changes from the floatation method and radiography methods correlated quite well. 

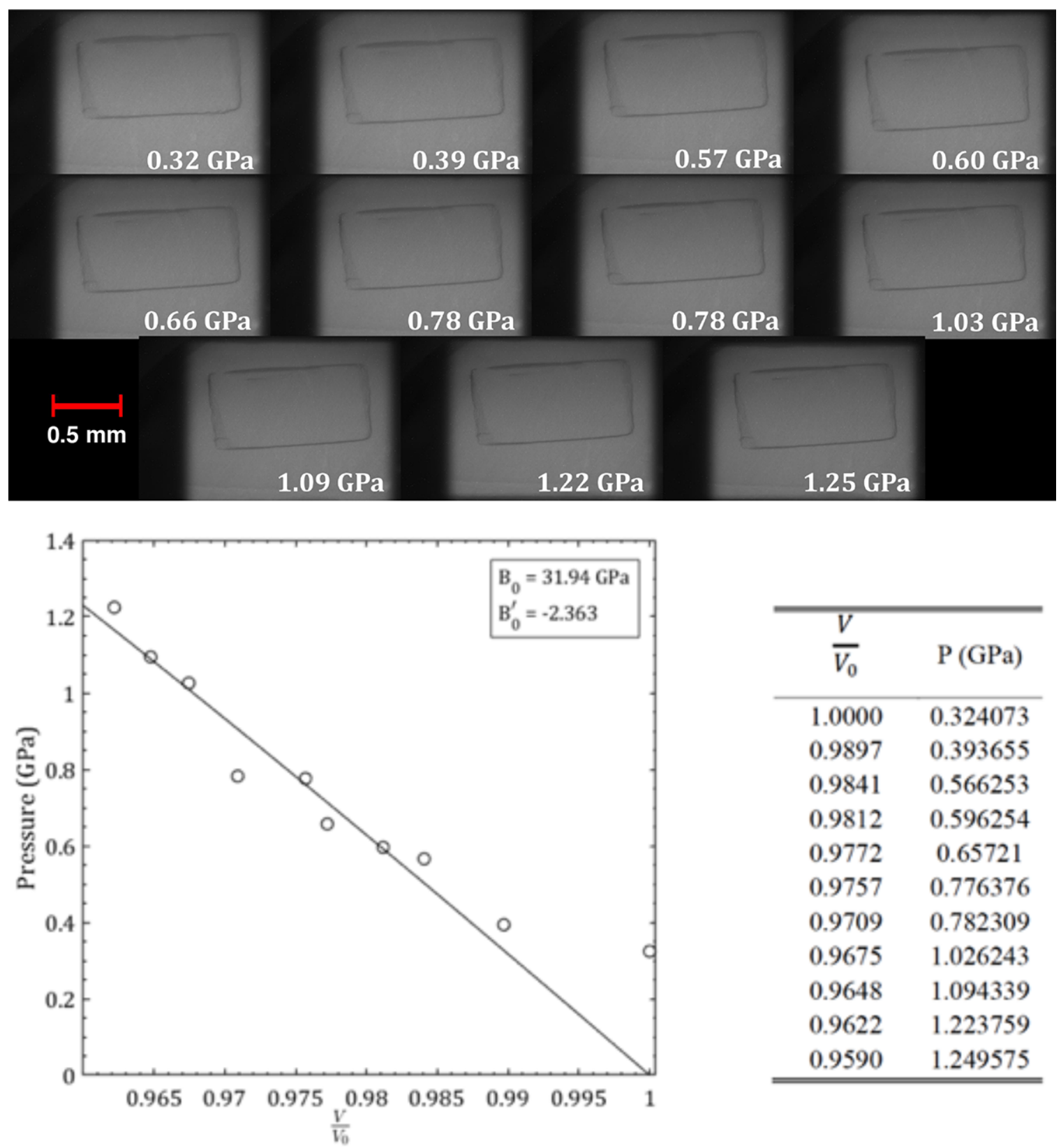

\begin{tabular}{cc}
\hline$\frac{V}{V_{0}}$ & $\mathrm{P}(\mathrm{GPa})$ \\
\hline 1.0000 & 0.324073 \\
0.9897 & 0.393655 \\
0.9841 & 0.566253 \\
0.9812 & 0.596254 \\
0.9772 & 0.65721 \\
0.9757 & 0.776376 \\
0.9709 & 0.782309 \\
0.9675 & 1.026243 \\
0.9648 & 1.094339 \\
0.9622 & 1.223759 \\
0.9590 & 1.249575 \\
\hline \hline
\end{tabular}

Figure 13. BOROFLOAT ${ }^{\circledR}$ radiography images used for Birch-Murnaghan equation of state fit. 


\section{GPa}

$1.8 \mathrm{GPa}$

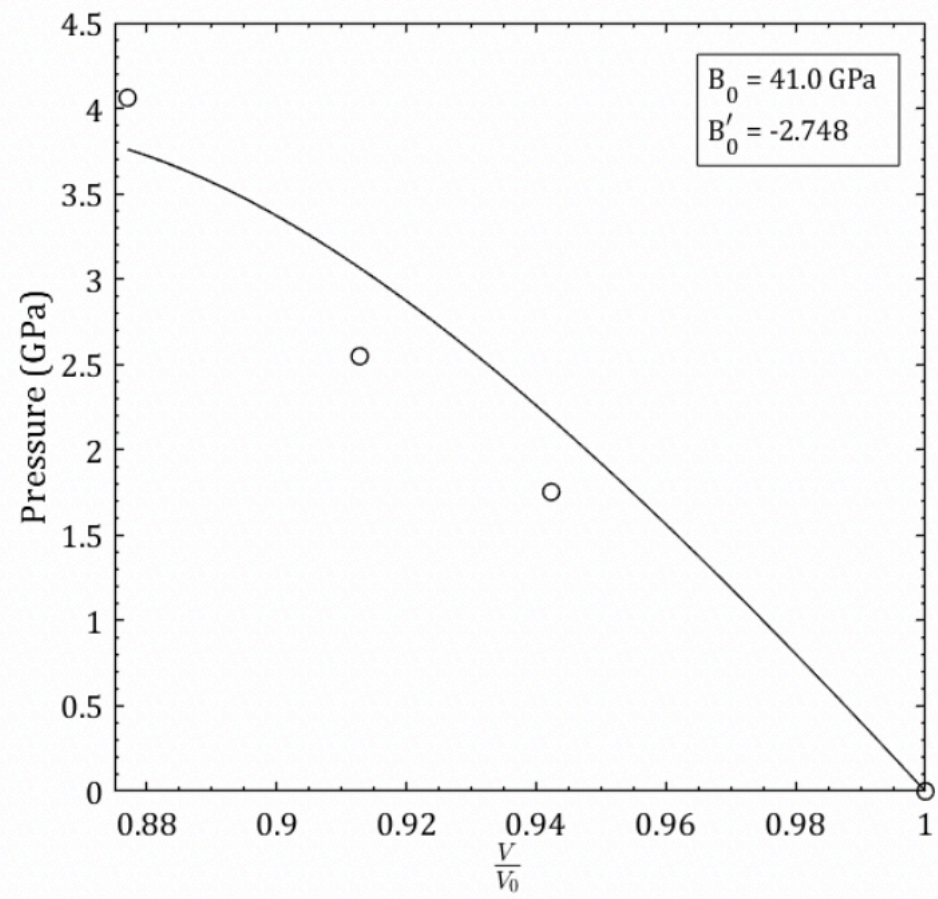

\begin{tabular}{cc}
\hline \hline $\begin{array}{c}\text { Pressure } \\
(\mathrm{GPa})\end{array}$ & $\mathrm{V} / \mathrm{V} 0$ \\
\hline 0 & 1 \\
1.8 & 0.9423 \\
2.5 & 0.9128 \\
4.1 & 0.8770 \\
\hline \hline
\end{tabular}

Figure 14. Starphire ${ }^{\circledR}$ radiography images used for Birch-Murnaghan equation of state fit. 


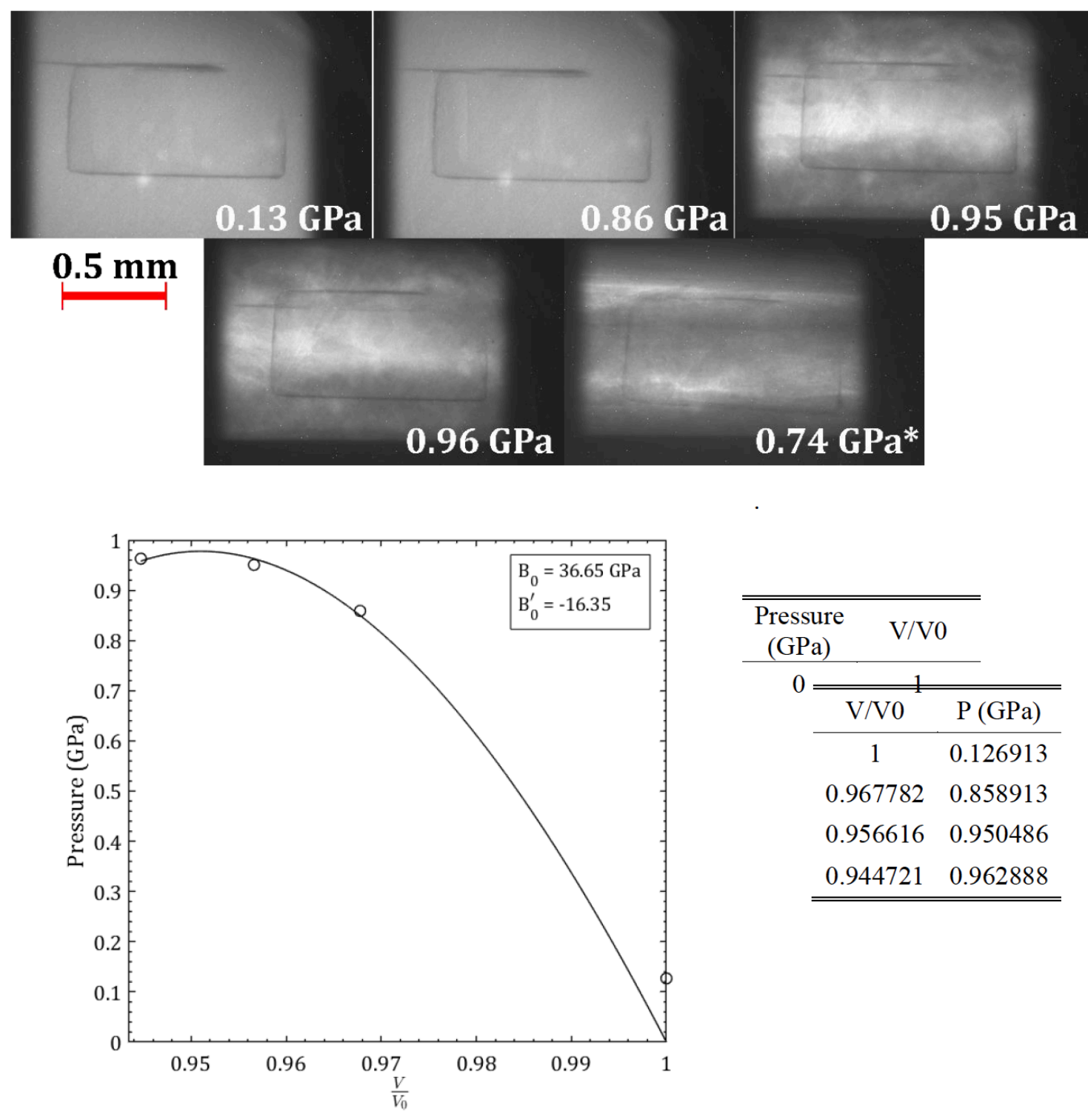

Figure 15. Fused quartz radiography images used for Birch-Murnaghan equation of state fit. Table 2. Bulk Modulus $\left(B_{0}\right)$ and first derivative of bulk modulus with respect to pressure $\left(B^{\prime}\right)$ ).

\begin{tabular}{|c|c|c|c|c|}
\hline \multirow{2}{*}{ Material } & \multicolumn{2}{|c|}{$\boldsymbol{B}_{\boldsymbol{0}}(\boldsymbol{G P a})$} & \multicolumn{2}{c|}{$\boldsymbol{B}_{\boldsymbol{0}}$} \\
\cline { 2 - 5 } & Reference & Radiography & Reference & Radiography \\
\hline Copper & $140.0[10]$ & $143.7^{*}$ & $4[10]$ & $3.904 *$ \\
\hline BOROFLOAT $^{\circledR}$ & $30.4[3]$ & 31.94 & N/A & -2.363 \\
\hline Starphire & $41.0[3]$ & 41.0 (fixed) & N/A & -3.93 \\
\hline Fused Quartz & $36.9[14]$ & 36.65 & $-4.666[14]$ & -16.35 \\
\hline
\end{tabular}

* From radiography measurements combined with copper diffraction. 


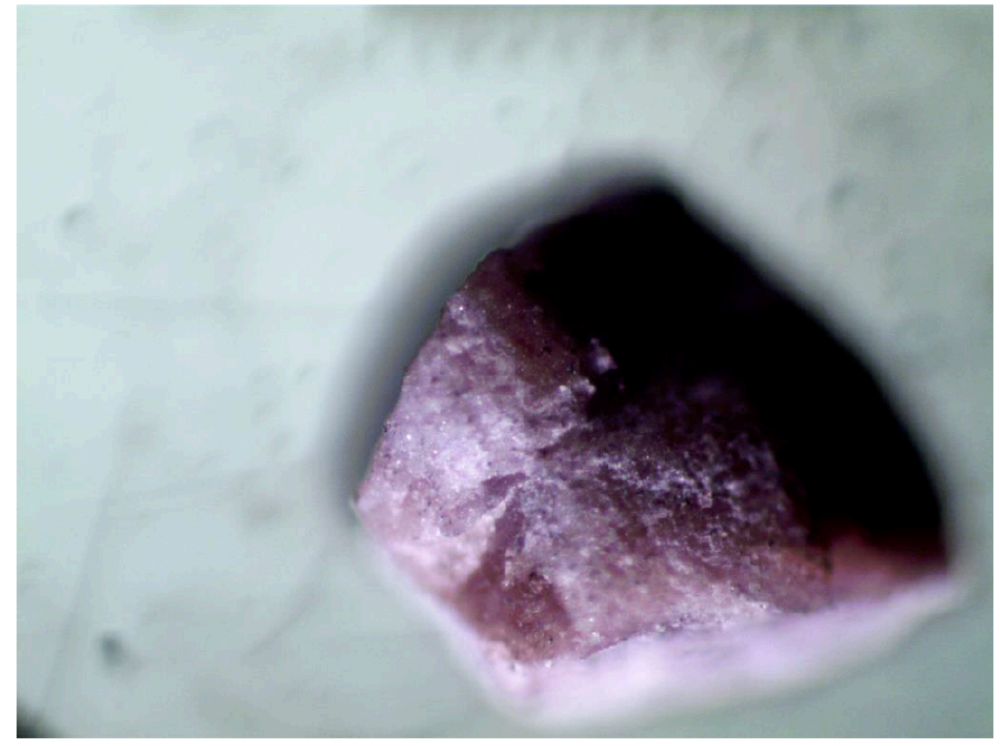

Figure 16. Recovered BOROFLOAT ${ }^{\circledR}$ sample $(1.0 \mathrm{~mm}$ height and $1.0 \mathrm{~mm}$ diameter) after pressurization to 4.7 GPa. 25X magnification.

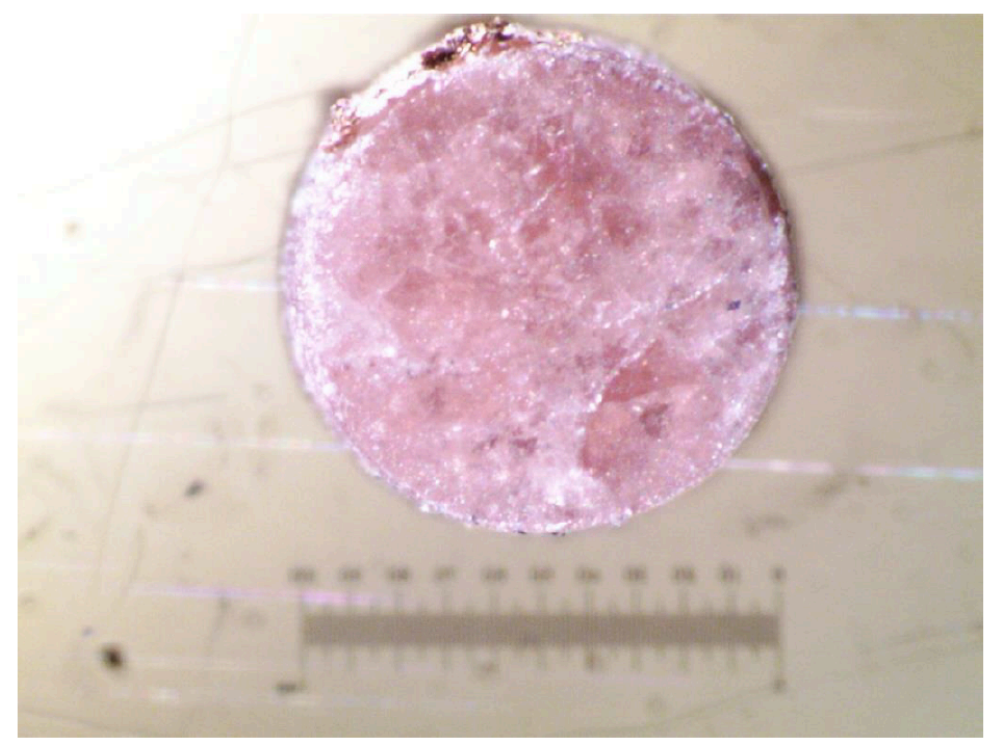

Figure 17. Recovered Starphire ${ }^{\circledR}$ sample (1 mm diameter, $0.5 \mathrm{~mm}$ height) after pressurization to $11.8 \mathrm{GPa}$. 25X magnification. 


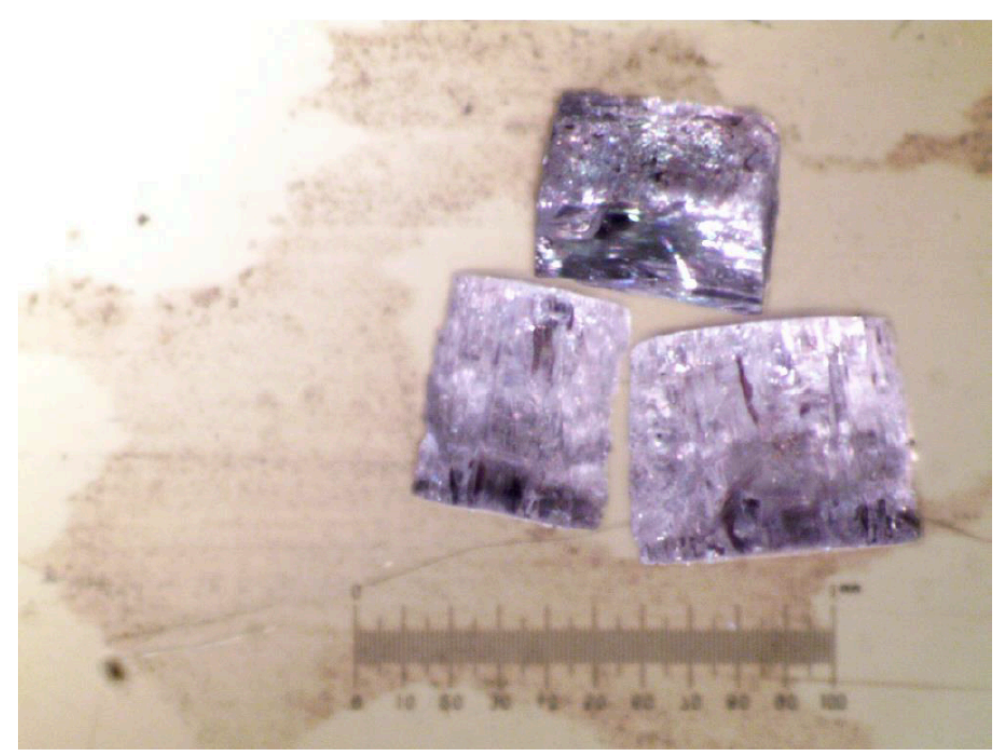

Figure 18. Recovered fused quartz sample (1 $1 \mathrm{~mm}$ diameter, $0.5 \mathrm{~mm}$ height) after pressurization to $11.8 \mathrm{GPa}$. 25X magnification.

Table 3. Comparison of initial and final densities from the PE anvil testing.

\begin{tabular}{|c|c|c|c|c|c|}
\hline Material & $\begin{array}{c}\boldsymbol{\rho}_{\mathbf{i}} \\
\left(\mathbf{g} / \mathbf{c m}^{\mathbf{3}}\right)\end{array}$ & $\begin{array}{c}\boldsymbol{\rho}_{\mathbf{f}} \\
\left(\mathbf{g} / \mathbf{c m}^{\mathbf{3}}\right)\end{array}$ & $\begin{array}{c}\mathbf{P}_{\max } \\
(\mathbf{G P a})\end{array}$ & $\begin{array}{c}\text { V/Vo (\%) } \\
\text { Density } \\
\text { Measurement }\end{array}$ & $\begin{array}{c}\text { V/Vo (\%) } \\
\text { Radiography }\end{array}$ \\
\hline BOROFLOAT $^{\circledR}$ & 2.215 & 2.333 & 4.7 & 94.94 & N/A \\
\hline Starphire & 2.499 & 2.552 & 11.8 & 97.92 & 97.58 \\
\hline Fused Quartz & 2.192 & 2.313 & 11.8 & 94.86 & 94.89 \\
\hline
\end{tabular}

\subsection{Apparent Yield Stress}

The estimated apparent yield stresses of BOROFLOAT ${ }^{\circledR}$ and Starphire ${ }^{\circledR}$ from the spherical indentation testing are listed in Table 4. The BOROFLOAT ${ }^{\circledR}$ had a lower apparent yield stress. Upon examination of apparent yield stresses for different diameter indenters for either material, their values were within $\sim 10 \%$ of one another.

Table 4. Apparent Yield Stress Results.

\begin{tabular}{|c|c|c|}
\hline $\begin{array}{c}\text { Spherical Indentation Method } \\
\text { and Indenter Diameter }\end{array}$ & BOROFLOAT $^{\circledR}$ & Starphire $^{\circledR}$ \\
\hline $\begin{array}{c}\text { Microindentation } \\
500 \mu \mathrm{m} \varnothing\end{array}$ & $\begin{array}{c}6.0-6.4 \mathrm{GPa} \\
\text { (ground \& polished) }\end{array}$ & $\begin{array}{c}6.9-7.3 \mathrm{GPa} \\
\text { (ground \& polished) }\end{array}$ \\
\hline $\begin{array}{c}5.5 \mathrm{GPa}-\text { air side } \\
\text { Microindentation }\end{array}$ & $\begin{array}{c}7.9 \mathrm{GPa}-\text { air side } \\
5.4 \mathrm{GPa}-\text { tin side } \\
\text { (As-processed surface) }\end{array}$ & $\begin{array}{c}7.0 \mathrm{GPa}-\text { tin side } \\
\text { (As-processed surface) }\end{array}$ \\
\hline $\begin{array}{c}5.8 \pm 0.2 \mathrm{GPa} \\
\text { Nanoindentation }\end{array}$ & $\begin{array}{c}6.7 \pm 0.2 \mathrm{GPa} \\
\text { (ground \& polished) }\end{array}$ \\
$6.4 \mu \mathrm{m} \varnothing[11]$ & \multicolumn{2}{|c}{ (ground \& polished) }
\end{tabular}

The initiation of permanent deformation from spherical indentation is caused by a superimposition of shear and hydrostatic pressure. The state of that multiaxial stress can be plotted on an elliptical yield surface of 
the tested material such as that shown in Fig. 19. This assumes that deformation initiates where the shear stress is a maximum, which is at location within the test material slightly beneath where the spherical indentation contact takes place; however, initiation is not guaranteed to take place there, and may in fact occur closer to, or at, the contact surface for materials that are more apt to "crush" or densify rather than deform via a shear mechanism. This effect continues to be explored by the authors.

The shape and position of the (quarter) elliptical yield surface shown in Fig. 19 may be unique for each material, and it captures a locus of shear-pressure combinations where the material exhibits the initiation of permanent yielding. A coarse estimation of the ellipse can result if one can measure the yield stresses from hydrostatic loading and from spherical indentation if the location of the onset of yielding is known. The authors hope to be able to confidently construct such a P-S $\mathrm{S}_{\text {eq }}$ yield surface in future work for various vitreous silicates.

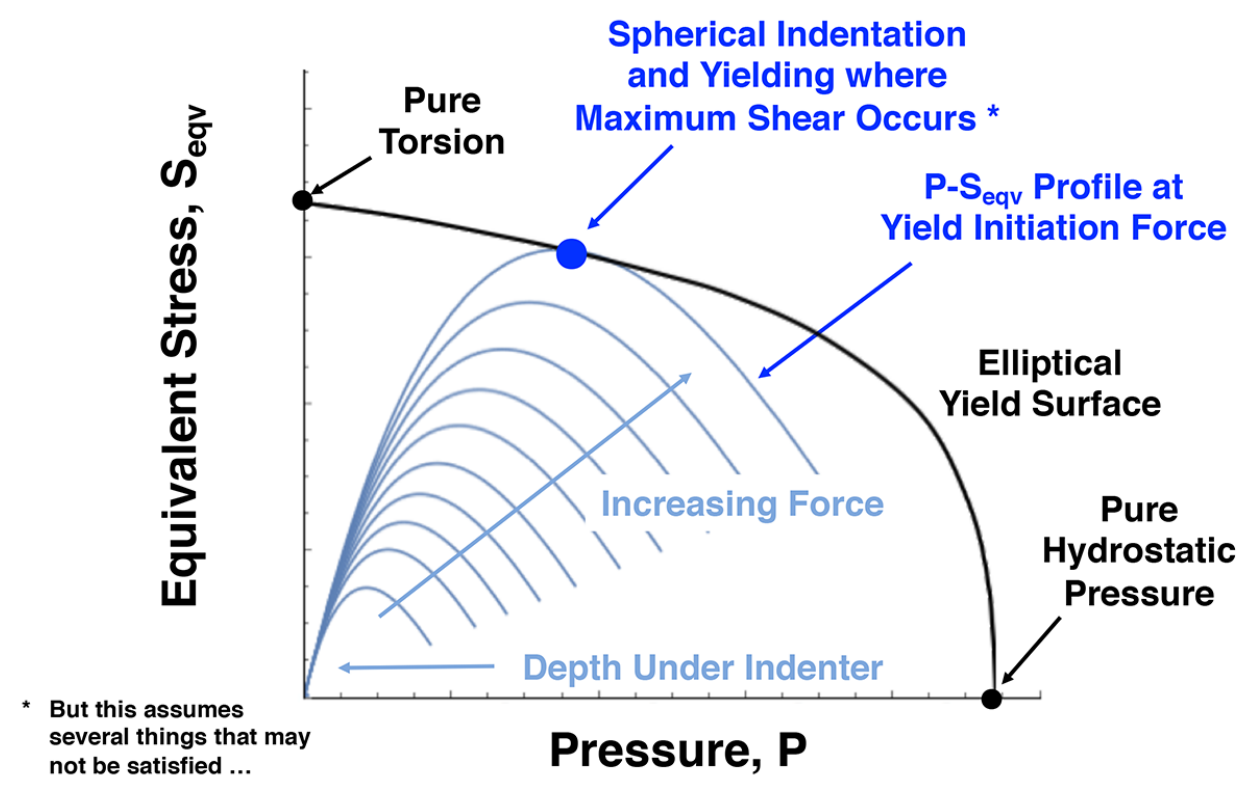

Figure 19. Spherical indentation response can provide a point on the Pressure-Equivalent Stress yield surface. 


\subsection{Initiation of Permanent Densification}

Both glasses showed evidence of the initiation of permanent densification between 4-6 GPa when tested with a DTDAC. The precision float method has been previously used by the authors [15], see Fig. 20, and trends of density as a function of maximum applied pressure in the DTDAC testing for the BOROFLOAT ${ }^{\circledR}$ and Starphire ${ }^{\circledR}$ are shown in Figs. 21-22. The magnitude of the DTDAC pressures equivalent to the magnitude of the apparent yield stresses estimated using spherical indentation. For an applied DTDAC pressure of $12 \mathrm{GPa}$, the uncompressed or permanent density of the BOROFLOAT ${ }^{\circledR}$ increased by $\sim 10 \%$ and that of the Starphire only by $\sim 4 \%$.

The DTDAC fixture subjects the specimen to "quasi-hydrostatic" loading, and while its geometry has been modeled before [6], an examination of the superimposed shear was not focused on. Therefore, a finite element model (FEM) was constructed to examine the nature of its stress state. The FEM is described in Fig. 23, and the resulting stress state is shown in Fig. 24. If those results are accurate, then different portions of the DTDAC specimen were subjected to different magnitudes and combinations of hydrostatic and shear stresses, and it is possible that different amounts of permanent densification consequently occurred in different portions of the specimen. Alternatives to this specimen for this examination are being explored by the authors in future work.

\section{Fused Quartz}

BOROFLOAT

STARPHIRE

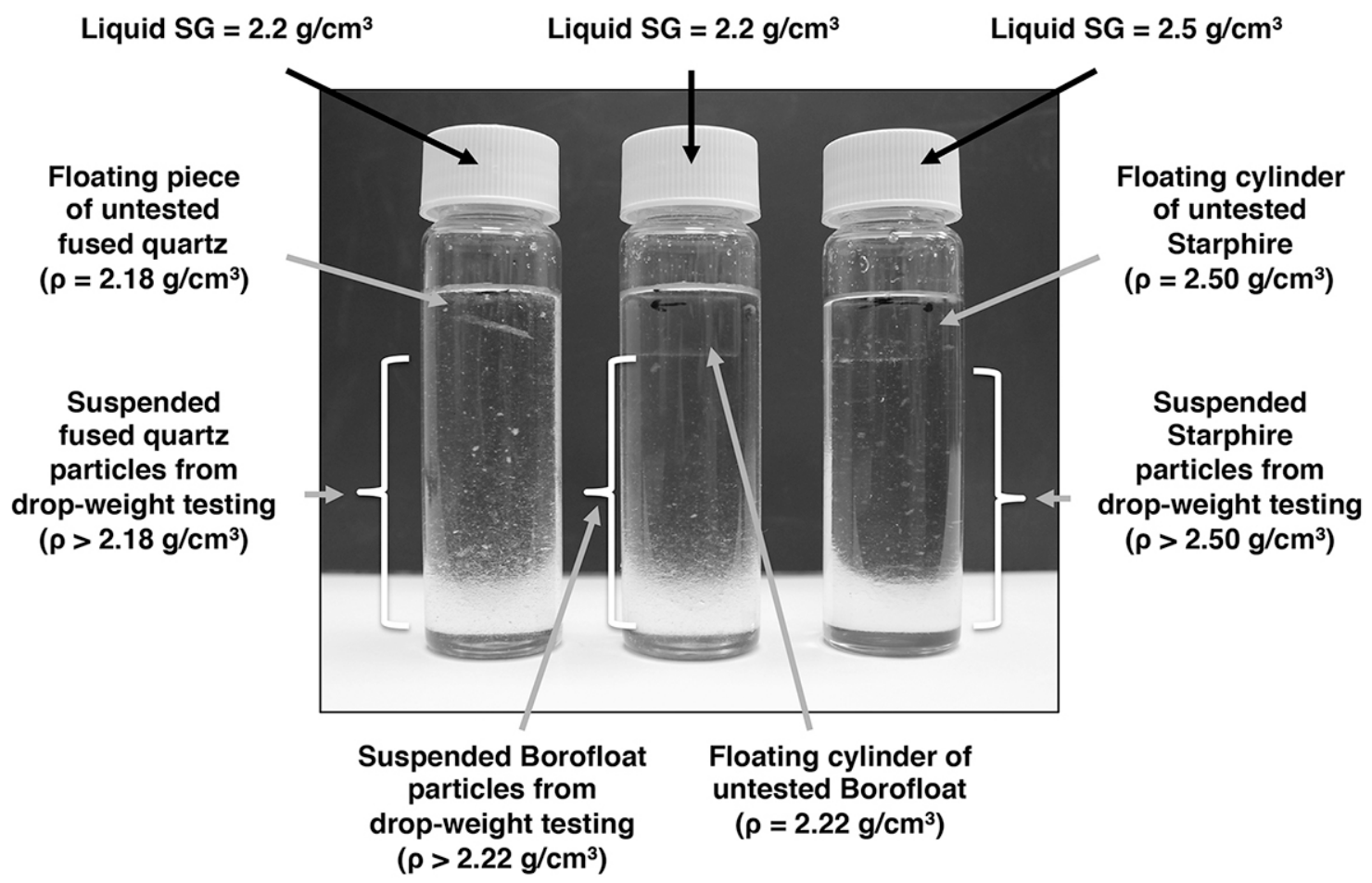

Figure 20. Float densification was used to characterize permanent density changes [15]. 


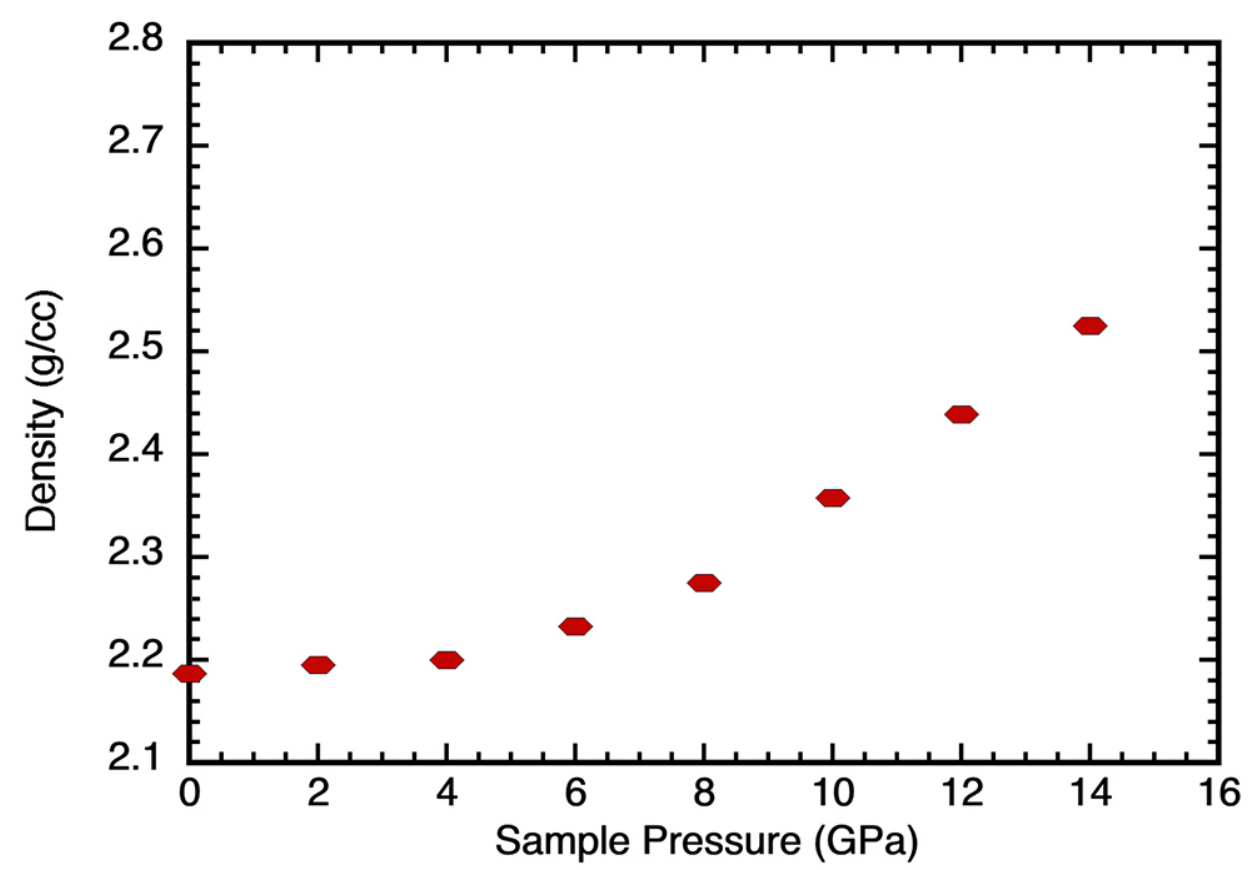

Figure 21. Density as a function of DTDAC sample pressure for BOROFLOAT ${ }^{\circledR}$.

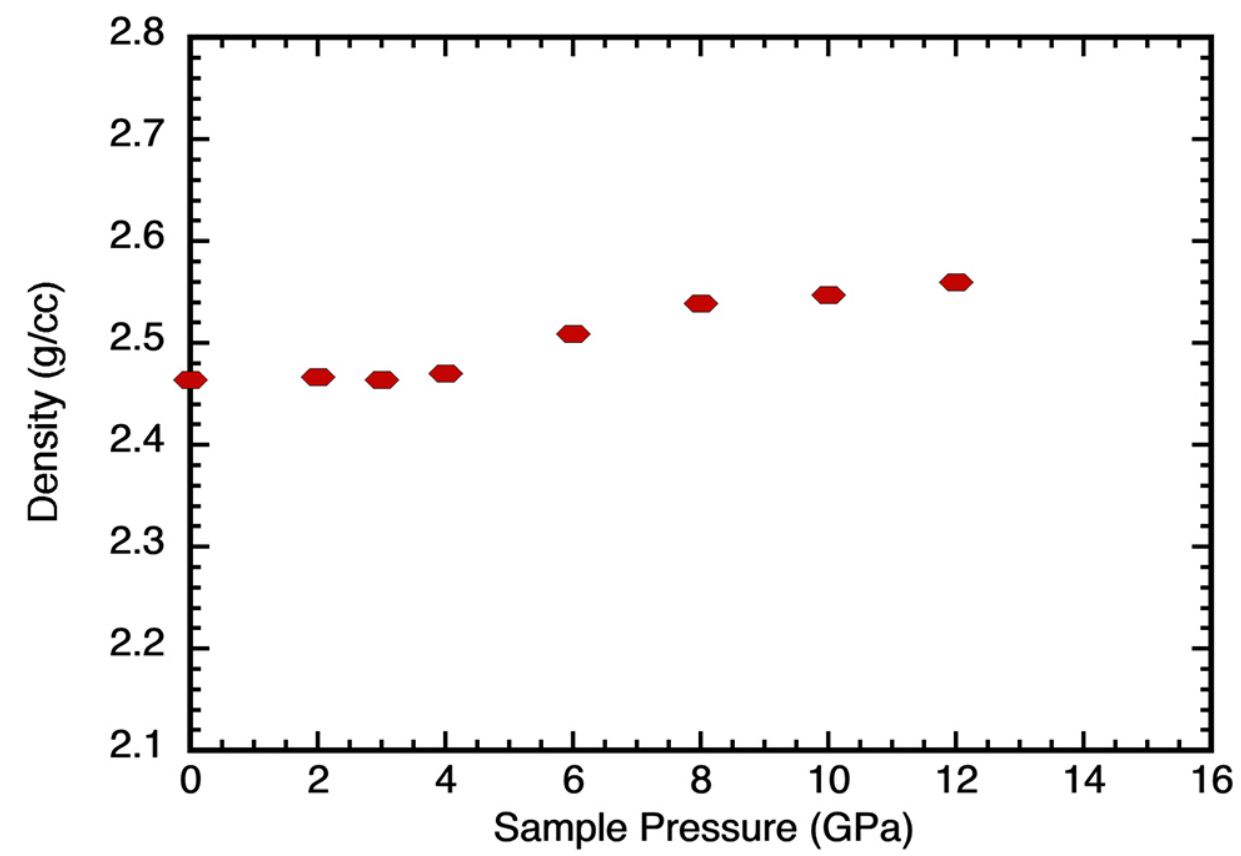

Figure 22. Density as a function of DTDAC sample pressure for Starphire ${ }^{\circledR}$. 
- 2-D quarter axisymmetric model

- Gasket thickness $=0.5 \mathrm{~mm}$

- Diamond anvil cell

- Steel gasket with yield strength of $1000 \mathrm{MPa}$

- Bilinear kinematic hardening to model yielding of the steel gasket. Assume tangent modulus to be $25 \%$ of elastic modulus

- Coefficient of friction assumed to be $\mathbf{0 . 5}$ between al contact surfaces

- Borosilicate glass sample

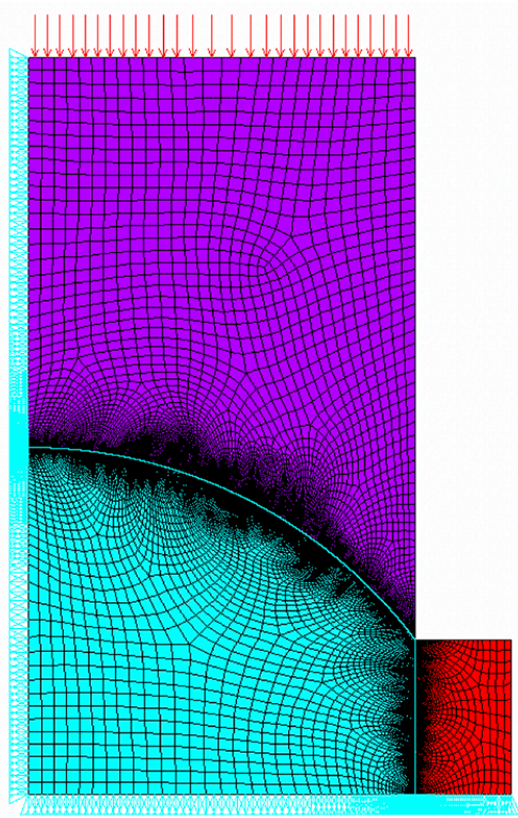

Figure 23. FEA model used to examine the multiaxial stress state in a DTDAC specimen.

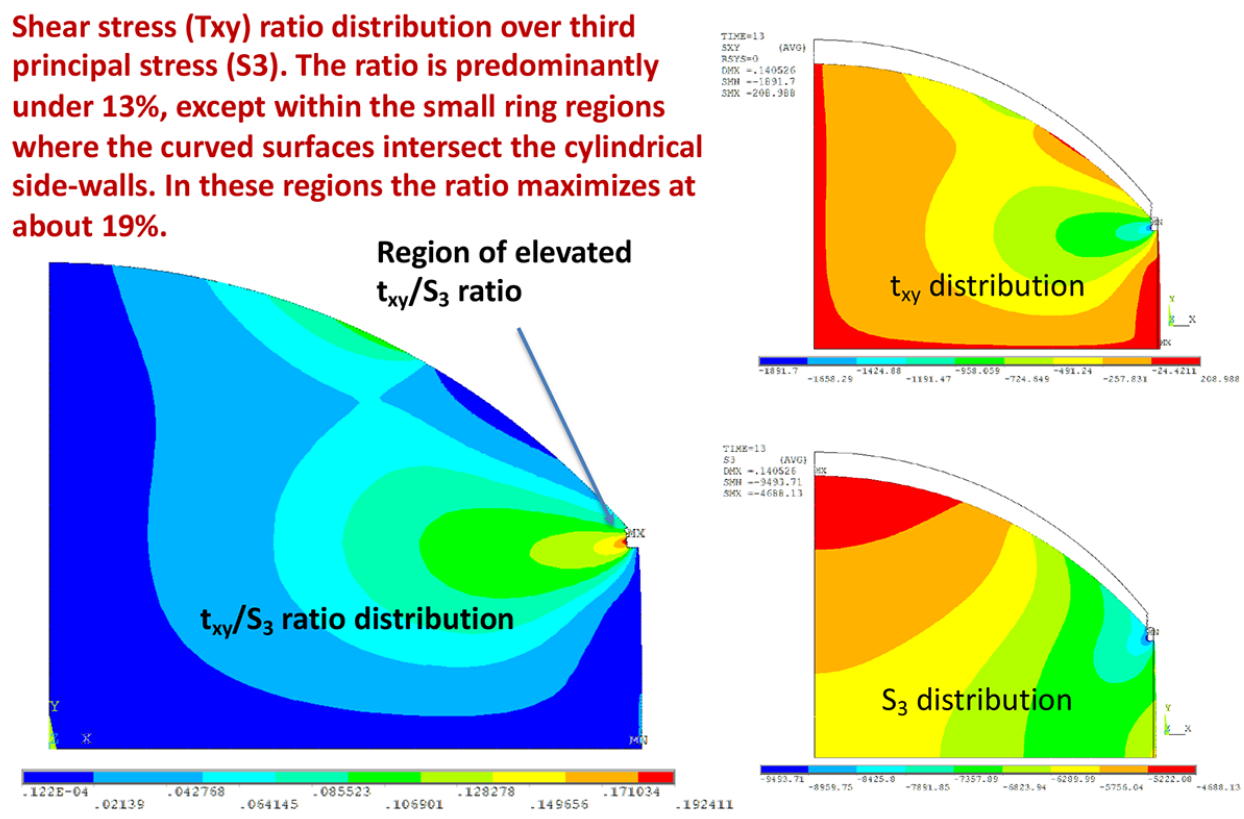

Figure 24. The superimposed shear and hydrostatic pressure of the DTDAC is an illustration of why its specimen is designated as having "quasi-hydrostatic" stress state. 


\section{CONCLUSIONS}

The equations of state (EOS's) for BOROFLOAT ${ }^{\circledR}$ and Starphire ${ }^{\circledR}$ vitreous silicates were developed using a combination of $\mathrm{x}$-ray radiography and quasi-static Paris-Edinburgh anvil testing. Volume change as a function of applied pressure was estimated. The radiography enables a means to estimate specimen volume contraction as the specimen is pressurized by the anvils. Such a method is attractive because it affords the opportunity to estimate volume change of pressurized amorphous materials which cannot be readily done using x-ray diffraction. The efficacy of the method was confirmed though the supplemental testing of copper and fused quartz; the resulting EOS's of those two materials were corroborated with other test methods.

The apparent yield stress of BOROFLOAT ${ }^{\circledR}$ and Starphire ${ }^{\circledR}$ were estimated using spherical indentation. The BOROFLOAT ${ }^{\mathbb{B}}$ had a lower apparent yield stress than Starphire. Because both materials densify, there is a possibility that the location of the initiation of permanent deformation does not occur where the shear stress is a maximum.

Both glasses showed evidence of the initiation of permanent densification between 4-6 GPa when tested with a double toroid diamond anvil cell. However, BOROFLOAT ${ }^{\circledR}$ permanently densified more than Starphire when they were both compressed to $12 \mathrm{GPa}$; namely, the uncompressed density of the BOROFLOAT ${ }^{\circledR}$ increased by $\sim 10 \%$ and that of the Starphire only by $\sim 4 \%$. The magnitude of these stresses is similar to the magnitude of the apparent yield stresses estimated using spherical indentation, so permanent densification of these glasses should be occurring in those indentation tests.

\section{REFERENCES}

[1] T. Rouxel, H. Ji, T. Hammouda, and A. Moreac, "Poisson's Ratio and the Densification of Glass under High Pressure," Physical Review Letters, 100:225501 (2008), doi: 10.1103/PhysRevLett.100.225501.

[2] C. S. Alexander, L. C. Chhabildas, W. D. Reinhard, and D. W. Templeton, "Changes to the shock response of fused quartz due to glass modification," International Journal of Impact Engineering, 35:1376-1385 (2008), doi: 10.1016/j.ijimpeng.2008.07.019.

[3] A. A. Wereszczak and C. E. Anderson, Jr., "Borofloat and Starphire Float Glasses: A Comparison," International Journal of Applied Glass Science, 5:334-344 (2014), doi: 10.1111/ijag. 12095.

[4] K. J. Ham, Y. K. Vohra, Y. Kono, A. A. Wereszczak, and P. Patel, "White-Beam X-ray Diffraction and Radiography Studies on High-Boron Containing Borosilicate Glass at High Pressures," High Pressure Research, 37:233-243 (2017), doi: 10.1080/08957959.2017.1287263.

[5] K. J. Ham, Y. Kono, P. J. Patel, S. M. Kilczewski, and Y. K. Vohra, "Pressure Induced Densification and Compression in a Reprocessed Borosilicate Glass," Materials, 11:114 (2018), doi: 10.3390/ma11010114.

[6] J. Fang, C. L. Bull, J. S. Loveday, R. J. Nelmes, and K. V. Kamenev, "Stress analysis and optimisation of double-toroidal anvils for high-pressure research," Review of Scientific Instruments, 83:093902 (2012), doi: 10.1063/1.4746993.

[7] B. L. Hackett, A. A. Wereszczak, and G. M. Pharr, "Effect of Aqueous-Based Mechanical Polishing on the Nanoindentation Response of Borosilicate Glasses," in review, International Journal of Applied Glass Science, 2018.

[8] F. Birch, "Finite Elastic Strain of Cubic Crystals," Physical Review, 71:809-824 (1947).

[9] Y. Fei, J. Li, K. Hirose, W. Minarik, J. Van Orman, C. Sanloup, W. van Westrenen, T. Komabayashi, and K. Funakoshi, "A critical evaluation of pressure scales at high temperatures by in situ X-ray 
diffraction measurements," Physics of the Earth and Planetary Interiors, 143-144:515-526 (2004), doi: 10.1016/j.pepi.2003.09.018.

[10] W. Wang, J. Zhang, H. Xu, Z. Lin, L. L. Daeman, Y. Zhao, and L. Wang, "Equation of state of bulk metallic glasses studied by an ultrasonic method," Applied Physics Letters, 94, 071904 (2009), doi: 10.1063/1.3085997.

[11] A. A. Wereszczak, T. G. Morrissey, M. K. Ferber, K. P. Bortle, E. A. Rodgers, G. Tsoi, J. M. Montgomery, Y. K. Vohra, and S. Toller, High Pressure Response of Silica, ORNL/TM-2013/4 Report, February, 2013.

[12] B. L. Hackett, A. A. Wereszczak, and G. M. Pharr, "Evaluation of New Technique to Estimate Yield Stress in Brittle Materials via Spherical Indentation Testing," Paper 06-01, Issue 2, Vol. 39, Ceramic Engineering and Science Proceedings, 2018.

[13] K. L. Johnson, Contact Mechanics, Cambridge University Press, Cambridge, 1985.

[14] W. H. Wang, P. Wen, L. M. Wang, Y. Zhang, M. X. Pan, D. Q. Zhao, and R. J. Wang, "Equation of state of bulk metallic glasses studied by an ultrasonic method," Applied Physics Letters, 79:39473949 (2001), doi: 10.1063/1.1426272.

[15] A. A. Wereszczak, S. B. Waters, R. J. Parten, and L. D. Pye, "Sub-micron fracture mechanism in silica-based glasses activated by permanent densification from high-strain loading," Journal of NonCrystalline Solids, 443:172-183 (2016), doi: 10.1016/j.jnoncrysol.2016.04.029. 
